\title{
Application of titanium-in-quartz thermobarometry to greenschist facies veins and recrystallized quartzites in the Hsuiehshan range, Taiwan
}

\author{
S. Kidder ${ }^{1, *}$, J.-P. Avouac ${ }^{1}$, and Y.-C. Chan ${ }^{2}$ \\ ${ }^{1}$ California Institute of Technology, Pasadena, CA, USA \\ ${ }^{2}$ Academia Sinica, Taipei, Taiwan \\ *now at: University of Otago, New Zealand \\ Correspondence to: S. Kidder (steven.kidder@otago.ac.nz)
}

Received: 23 May 2012 - Published in Solid Earth Discuss.: 8 June 2012

Revised: 22 October 2012 - Accepted: 27 October 2012 - Published: 7 January 2013

\begin{abstract}
The accuracy, reliability and best practises of Tiin-quartz thermobarometry (TitaniQ) in greenschist facies rocks have not been established. To address these issues, we measured $\mathrm{Ti}$ concentrations in rutile-bearing samples of moderately deformed, partially recrystallized quartzite and vein quartz from the Hsüehshan range, Taiwan. The spread of Ti concentrations of recrystallized grains in quartzite correlates with recrystallized grain size. Recrystallized quartz (grain size $\sim 100-200 \mu \mathrm{m}$ ) that formed during early deformation within the biotite stability field shows a marked increase in intermediate Ti-concentration grains $(\sim 1-10 \mathrm{ppm})$ relative to detrital porphyroclasts $(\mathrm{Ti} \sim 0.1-200 \mathrm{ppm}$ ). Fine recrystallized quartz ( $\sim 5 \%$ of the samples by area, grain size $\sim 10-20 \mu \mathrm{m}$ ) has a further restricted Ti concentration peaking at $0.8-2 \mathrm{ppm}$. This trend suggests equilibration of Ti in recrystallized quartz with a matrix phase during deformation and cooling. Unlike previously documented examples, Ti concentration in the quartzite is inversely correlated with blue cathodoluminescence. Deformation was associated with a minimum grain boundary diffusivity of Ti on the order of $10^{-22} \mathrm{~m}^{2} \mathrm{~s}^{-1}$. Vein emplacement and quartzite recrystallization are independently shown to have occurred at $250-350^{\circ} \mathrm{C}$ and $300-410^{\circ} \mathrm{C}$, respectively, with lithostatic pressure of 3$4 \mathrm{kbar}$ (assuming a geothermal gradient of $25^{\circ} \mathrm{km}^{-1}$ ), and with hydrostatic fluid pressure. Estimates of the accuracy of TitaniQ at these conditions depend on whether lithostatic or fluid pressure is used in the TitaniQ calibration. Using lithostatic pressure and these temperatures, the Thomas et al. (2010) calibration yields Ti concentrations within error
\end{abstract}

of concentrations measured by SIMS. If fluid pressure is instead used, predicted temperatures are $\sim 30-40^{\circ} \mathrm{C}$ too low. TitaniQ has potential to yield accurate PT information for vein emplacement and dynamic recrystallization of quartz at temperatures as low as $\sim 250^{\circ} \mathrm{C}$, however clarification of the relevant pressure term and further tests in rutile-present rocks are warranted.

\section{Introduction}

Titanium-in-quartz thermobarometry (referred to hereafter as TitaniQ; Wark and Watson, 2006; Thomas et al., 2010; Huang and Audétat, 2012) has significant potential as a tool for constraining pressure and temperature of deformation independently of major-element exchange thermobarometers. TitaniQ is based on the temperature- and pressuredependent substitution of $\mathrm{Ti}$ for $\mathrm{Si}$ in quartz in the presence of rutile or other Ti-bearing phases. Previous workers have found reasonable consistency between TitaniQ and traditional thermobarometry in metamorphic rocks at temperatures above $\sim 500^{\circ} \mathrm{C}$ (Rusk et al., 2008; Spear and Wark, 2009; Storm and Spear, 2009; Pennacchioni et al., 2010; Grujic et al., 2011; Menegon et al., 2011; though see also Kawasaki and Osanai, 2008; Raimondo et al., 2011). At lower temperatures results are less clear. Spear and Wark (2009) found TitaniQ temperatures of $425-475^{\circ} \mathrm{C}$ in samples with garnet-biotite temperatures of $475-530^{\circ} \mathrm{C}$, and suggested that the quartz recrystallized at the lower temperatures 
during prograde metamorphism. Kohn and Northrup (2009), Peterman and Grove (2010), Rasmussen et al. (2011), and Behr and Platt (2011) used TitaniQ to estimate temperatures as low as $280^{\circ} \mathrm{C}$ in some samples, however the accuracy of these results has not been systematically verified with independent quantitative PT constraints. Grujic et al. (2011) found that $\mathrm{Ti}$ concentrations in quartz in low-temperature mylonites were not reset during dynamic recrystallization, and Behr and Platt (2011) found both significantly higher and lower Ti-concentrations than expected in more than a third of their samples. A further complication is that the TitaniQ calibration used in the most of the above studies (Thomas et al., 2010) was challenged by Huang and Audétat (2012), who estimate that temperatures should be $100^{\circ} \mathrm{C}$ (or more) higher than those calculated in the above-cited examples.

The above studies raise significant questions regarding the use of TitaniQ for estimating temperature and pressure in greenschist facies rocks: Does quartz dynamically recrystallized at low temperatures equilibrate with respect to Ti concentration? If so, how is equilibration affected by deformation time scale, strain, and lithology? Does equilibration depend on recrystallization mechanisms (Grujic et al., 2011)? How well does TitaniQ perform when extrapolated to $400^{\circ} \mathrm{C}$ below its experimental calibration?

We studied partially recrystallized quartz in rutilebearing rocks from the Hsüehshan range of central Taiwan. The Hsüehshan range has a relatively simple and wellconstrained deformation history at greenschist facies conditions (e.g. Beyssac et al., 2007). We supplement and describe available PT constraints, quantify Ti concentrations and changes in Ti concentration associated with recrystallization, compare these results to Ti concentrations expected using two TitaniQ calibrations, and make recommendations for future development and use of Ti-in-quartz thermobarometry.

\section{Geologic background}

The Hsüehshan range, Taiwan, (Figs. 1 and 2) comprises lithified coarse- to medium-grained sands and muds deposited in the Chinese continental margin during early Tertiary rifting (Ho, 1988). The strata experienced a broadly two-phase geologic history characterized by early, minor extension and later compression due to collision of the Luzon volcanic arc with the Chinese continental margin (e.g. Ho, 1986). An unconformity separating the passive margin sequence from a foreland overlap sequence dates the onset of collision near the latitude of the study at $\sim 6.5 \mathrm{Ma}$ (Lin et al., 2003).

Structural characteristics of the Hsüehshan range are described by Tsan (1971), Lu (1992), Lu et al. (1991; 1997), Tillman et al. (1992), Clark et al. (1992, 1993), Tillman and Byrne (1995, 1996), Fisher et al. (2002), and Kidder et al. (2012). Early extensional deformation is associated with

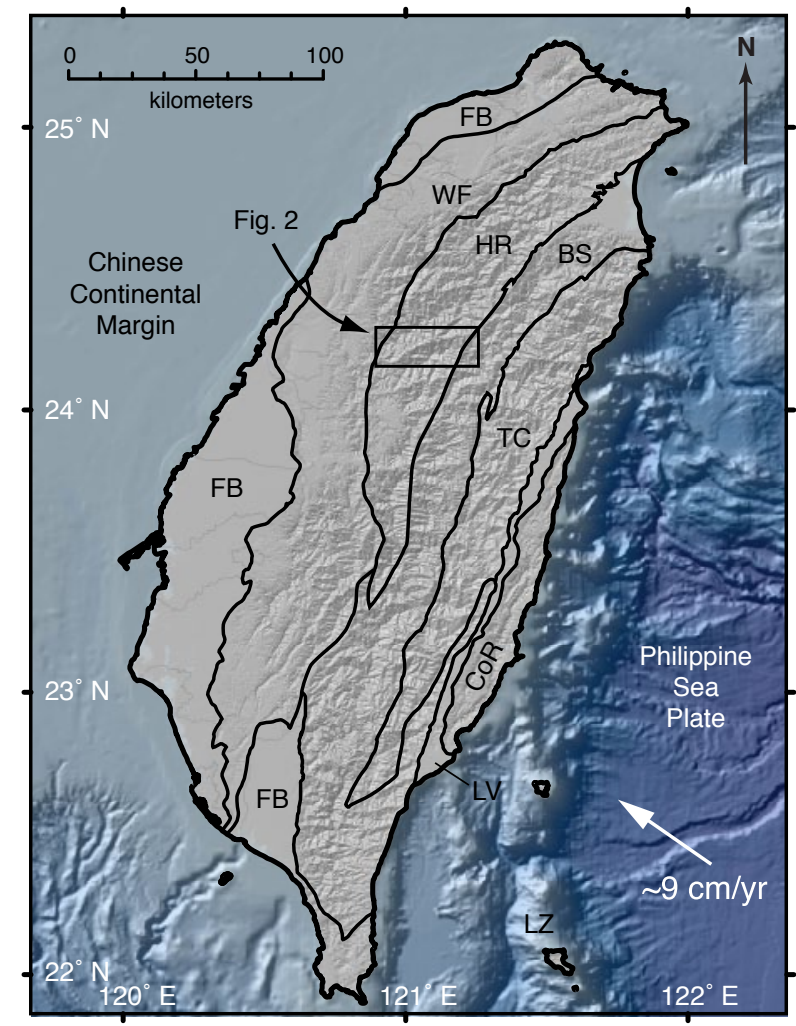

Fig. 1. Shaded relief map of Taiwan showing simplified tectonic provinces modified after Ho (1988): FB, foreland basin; WF, western foothills; HR, Hsüehshan range; BS, Backbone slates; TC, PreTertiary Tananao complex; LV, Longitudinal Valley; CoR, Coastal Range; LZ, Luzon Volcanic Arc. Study area is located within the box labeled "Fig. 2." Plate convergence rate (white arrow) is from Sella et al. (2002).

minor normal faults and quartz veining (Lu et al., 1991; Tillman et al., 1992; Clark et al., 1993). Overprinting compressional deformation features include upright folds (e.g. Figs. 2 and 3), thrust faults, and a subvertical axial-planar foliation (e.g. Fig. 2b) defined by slatey cleavage, pressure solution seams, and flattened detrital grains (e.g. Tillman and Byrne, 1995). Synkinematic fibers in pressure shadows in slates indicate that throughout most of the range compressional deformation was co-axial with a horizontal shortening direction (Clark et al., 1993; Tillman and Byrne, 1995). Internal strain generally increases from west to east across the Hsüehshan range. Quartzites in the west of the range show little to no internal deformation and preserve a variety of sedimentary features, whereas quartzites in the east (as described below) are penetratively strained. Slates record a minimum of $\sim 30 \mathrm{~km}$ horizontal shortening (Fisher et al., 2002), with minimum measured strains (e.g. Fig 2b) similar to those recorded in quartzites (Kidder et al., 2012). Total strains in slates could be significantly larger. Veins are common in the core of the Hsüehshan range (particularly within and between the two 


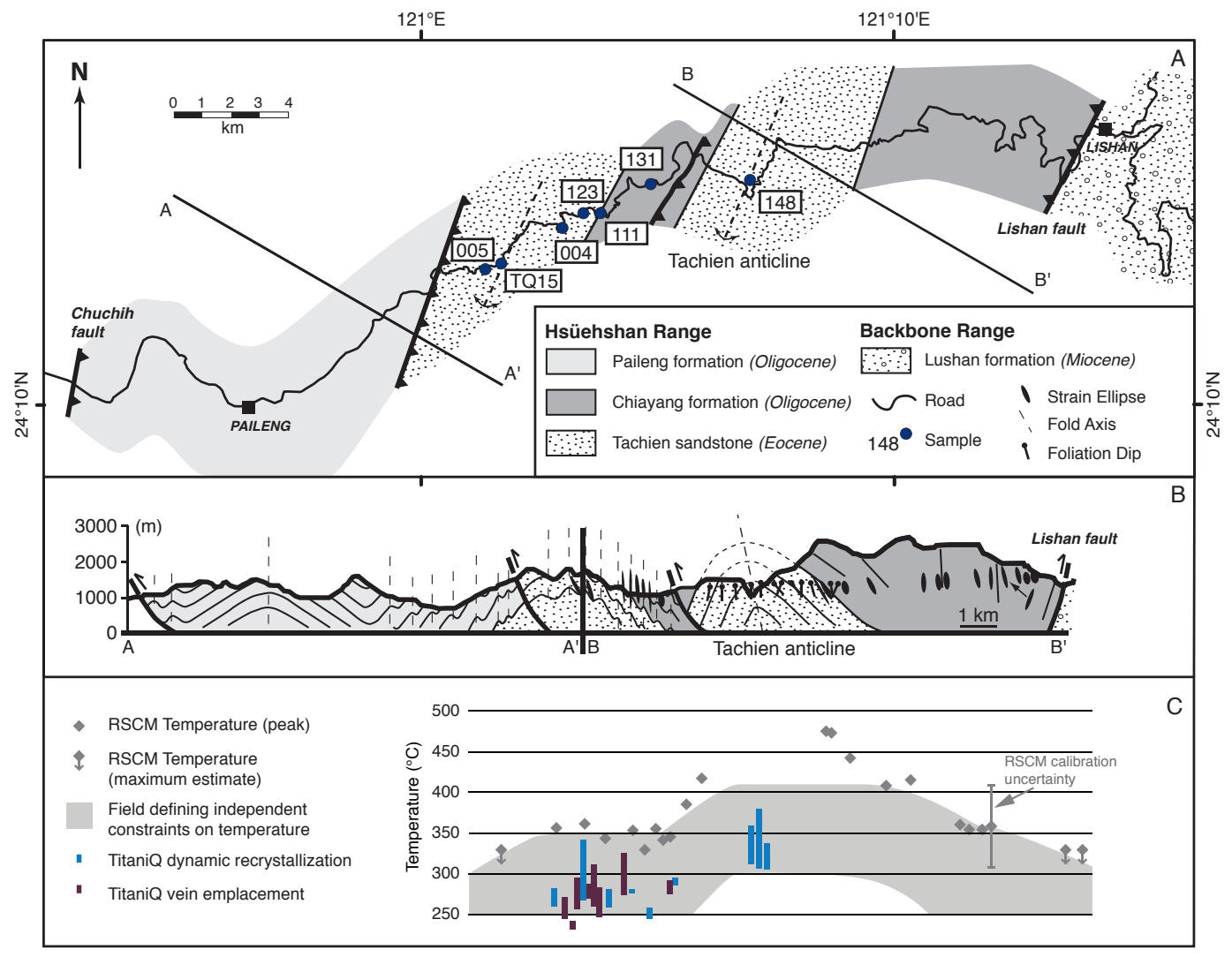

Fig. 2. (A) Geologic map of a portion of the Hsüehshan range based on Tillman and Byrne (1995) and Ho (1988) showing rock units, major structures and sample locations. (B) Composite cross section based on Tillman and Byrne (1995) showing their strain ellipse data from slates and our foliation analyses from quartzites. (C) Independent temperature constraints and TitaniQ temperature estimates (Thomas et al., 2010) plotted relative to location on the cross section. Lithostatic pressures associated with the TitaniQ estimates are $\sim 2.5-3.5 \mathrm{kbar}$ (assuming a geothermal gradient of $25^{\circ} \mathrm{C} \mathrm{km}^{-1}$ ). A TiO 2 activity of 1.0 is assumed based on the presence of rutile in all samples. Grey diamonds are peak temperatures from Raman spectroscopy of carbonaceous material ("RSCM"). RSCM and microstructural-based constraints discussed in the text limit "bulging" recrystallization of quartz to the area shaded in grey. TitaniQ vein emplacement temperatures (unrecrystallized vein quartz) with independent maximum and minimum temperature constraints (grey shaded region) are shown in purple. TitaniQ temperatures for dynamically recrystallized vein quartz and quartzite are shown in blue (also independently constrained to lie within the grey shaded region).

exposures of Tachien sandstone), and are concentrated within the axial zones of folds (e.g. Fig. 3). Veins are virtually absent in the Chiayang formation east of the Tachien anticline.

Metamorphism throughout the Hsüehshan range is greenschist facies, with the highest reported temperatures of $\sim 475^{\circ} \mathrm{C}$ reached near the core of the Tachien anticline (Fig. 2; Beyssac et al., 2007) based on Raman spectroscopy of carbonaceous material (RSCM, Fig. 2c). Temperatures were at or near peak conditions at the onset of deformation. Beyssac et al. (2007) suggested that peak temperatures were acquired under "static" conditions prior to collision since peak temperatures based on traditional metamorphic phase equilibria are lower than those indicated by RSCM (Beyssac et al., 2007) and deformation facilitates metamorphic recrystallization but has relatively little effect on RSCM. Beyssac et al. (2007) and Chen et al. (2011) additionally point to a corre- lation between RSCM temperature and stratigraphic depth in uplifted strata as evidence that collisional-deformation postdated peak metamorphic conditions. We provide evidence below that temperatures were at least $\sim 400{ }^{\circ} \mathrm{C}$ in the core of the Tachien anticline at the onset of deformation. Potential temperature-time paths and available thermochronologic data are depicted in Fig. 4.

\section{Methods}

Thin sections were made from 50 samples of quartzite and quartz veins. Eight representative samples were selected for further study. The selected samples were polished, cleaned with isopropyl alcohol and coated with $\sim 30 \mathrm{~nm} \mathrm{Au}$. Ti concentrations in quartz were analysed on the Cameca $7 \mathrm{f}$ Secondary Ion Mass Spectrometer (SIMS) at the California 


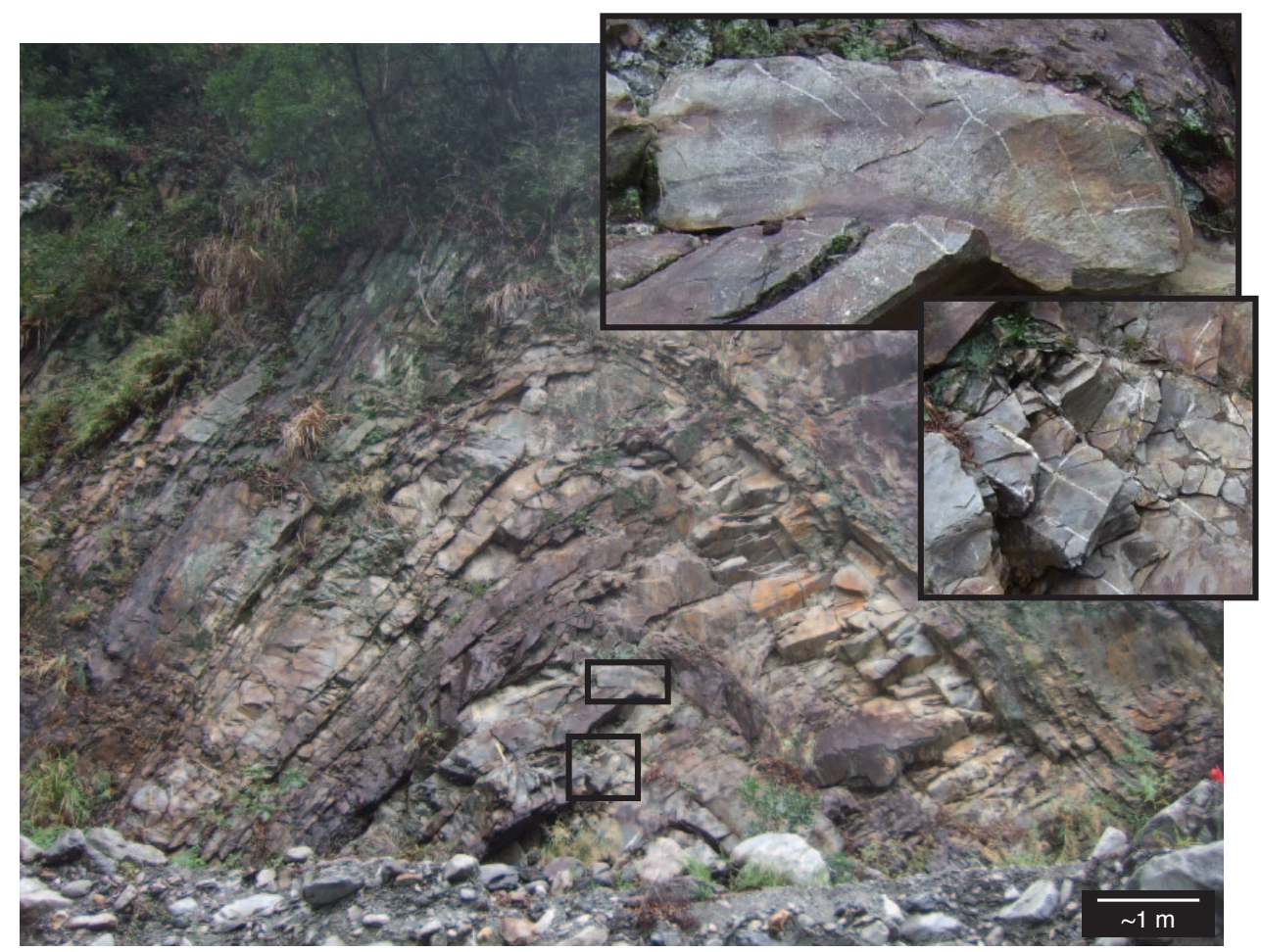

Fig. 3. Anticline within the Chiayang formation, and location of sample $131 \mathrm{~g}$. The outcrop is dominantly quartzite, with minor slate interbeds. Insets show examples of veins formed in the hinge zone of the anticline during folding.
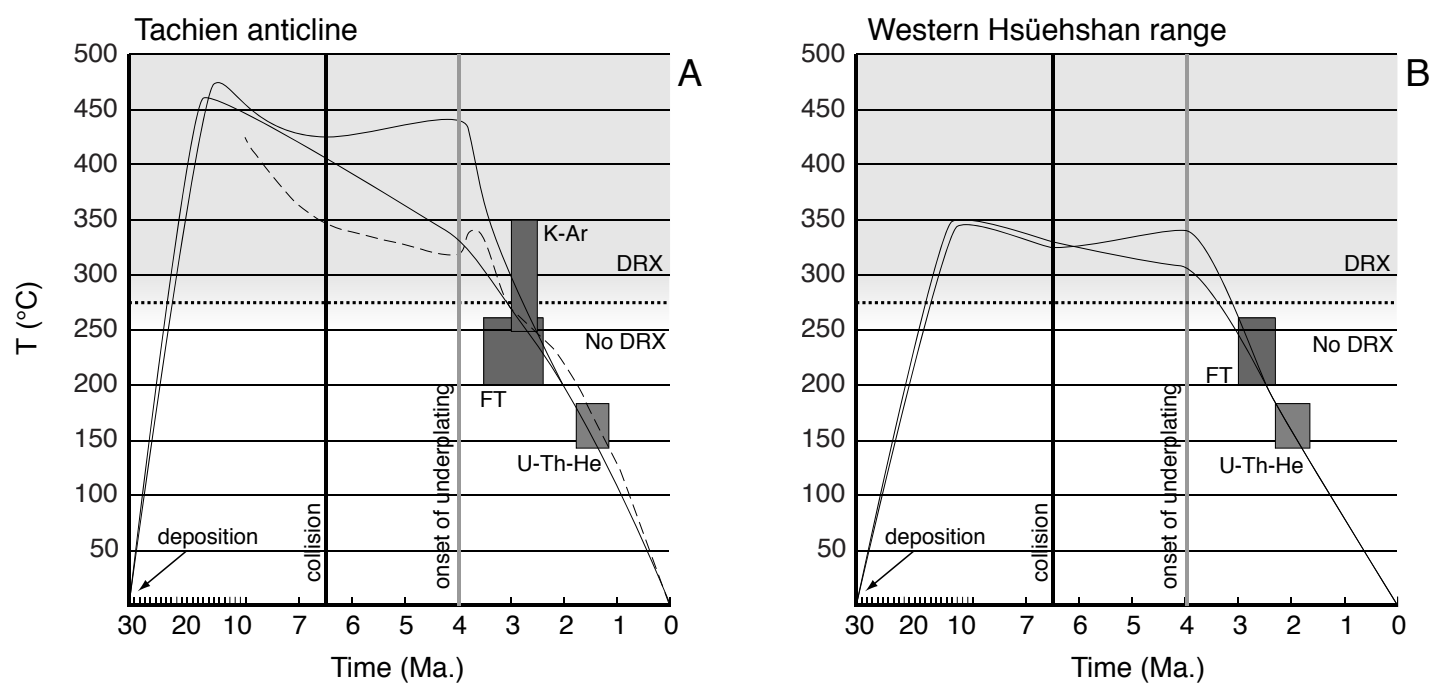

Fig. 4. Constraints on temperature-time history and possible cooling paths for (A) the deepest exposed levels of the Hsüehshan range where quartzites $148 \mathrm{~d}$ and $148 \mathrm{j}$ were sampled, and $(\mathbf{B})$ the cooler region to the west where the remainder of samples were collected. Cooling rates since $\sim 3 \mathrm{Ma}$ are well constrained at $\sim 90^{\circ} \mathrm{Myr}^{-1}$ by zircon fission track (Liu et al., 2001), zircon U-Th-He (Beyssac et al., 2007), and white mica K-Ar data (Tsao, 1996). Note that the $\mathrm{x}$-axis is compressed by a factor of 10 between 30 and $8 \mathrm{Ma}$. The dashed line reproduces the results of the thermal-kinematic model of Simoes et al. (2007). The thin black lines represent cooling paths constrained by evidence of elevated temperatures at the onset of collision. Grey shading and dotted horizontal line demarcate temperatures where dynamic recrystallization (DRX) occurs in quartz. Closure temperatures for K-Ar data on a set of $<2 \mu \mathrm{m}$ white mica grains span the values quoted by Tsao (1996) and a lower temperature suggested by Beyssac et al. (2007) for these data. 
Institute of Technology using a ${ }^{16} \mathrm{O}^{-}$primary ion beam. In the first of four sessions, we used a beam current of 4 $5 \mathrm{nA}$, a mass resolving power of $\sim 3000$, and analysed masses ${ }^{27} \mathrm{Al},{ }^{28} \mathrm{Si},{ }^{40} \mathrm{Ca},{ }^{47} \mathrm{Ti},{ }^{48} \mathrm{Ti},{ }^{49} \mathrm{Ti}$ and ${ }^{56} \mathrm{Fe}$. For faster analysis time in the remaining sessions, we used a beam current of 7-30 nA, a mass resolving power of $\sim 4000$, and analysed masses ${ }^{27} \mathrm{Al},{ }^{30} \mathrm{Si},{ }^{44} \mathrm{Ca},{ }^{47} \mathrm{Ti}$ and ${ }^{49} \mathrm{Ti}$. Prior to each analysis, we rastered for $60 \mathrm{~s}$ over a $50 \times 50 \mu \mathrm{m}$ area. We used a field aperture of $100 \mu \mathrm{m}$ to avoid surface contamination. In an early set of (discarded) analyses using a $400 \mu \mathrm{m}$ aperture, Ti counts in samples containing less than $\sim 1 \mathrm{ppm}$ Ti steadily decreased over $>1200 \mathrm{~s}$ and failed to reach Ti concentrations later found using a $100 \mu \mathrm{m}$ aperture. No temporal decay in Ti-contamination was evident using the $100 \mu \mathrm{m}$ aperture. Effective spot size using the small aperture is $8-10 \mu \mathrm{m}$.

Raw data were minimally filtered. We inspected and compared trends in element ratios for each analysis and removed 11 spots (of 560 total) that could be shown with reasonable certainty to have intersected non-quartz phases. This judgment call was made when two or three trace elements at the same spot were highly irregular or when high Ti concentration coincided with petrographic evidence that the beam encountered non-quartz phases. Because of the difficulty in confidently distinguishing micro- or nano-inclusions encountered in a SIMS analysis from quartz (which could contain fine-scale compositional anomalies), we did not filter out occasional mass cycles with anomalous trace element contents. Instead, all mass cycles were used to estimate Ticoncentrations. Our approach was to minimise subjective biases introduced by picking outliers, and use median estimates and standard errors to estimate mean values and uncertainties since these statistics are better suited for noisy data than the arithmetic mean and standard deviation.

Analyses that are likely to have intersected grain boundaries or cracks are noted in the Supplement. We carried out a few test analyses of cracks in large, low-Ti quartz grains to determine whether they yield anomalous $\mathrm{Ti}$ concentrations (e.g. due to contamination during polishing). These analyses showed no higher Ti concentrations than adjacent quartz. Based on this result, and the difficulty in fine-grained recrystallized zones of establishing whether or not an analysis intersected a grain boundary, we did not discard analyses that may have intersected grain boundaries.

We used a regression line constrained through the origin (Fig. 5) to calculate Ti concentrations using National Institute of Standards (NIST) glasses 610 and $612(434 \pm 15$ and $44 \pm 5$ ppm $\mathrm{TiO}_{2}$, respectively, Jochum et al., 2005). To account for matrix effects between quartz and NIST glass, we used the correction factor determined by Behr et al. (2010). While such corrections could potentially change over time and under different SIMS environments, we note that the Behr et al. (2011) analyses were carried out on the same SIMS used in this study and that measured Ti/Si ratios for NIST glasses for the two studies are within error. The robustness of the correction factor is additionally suggested by its

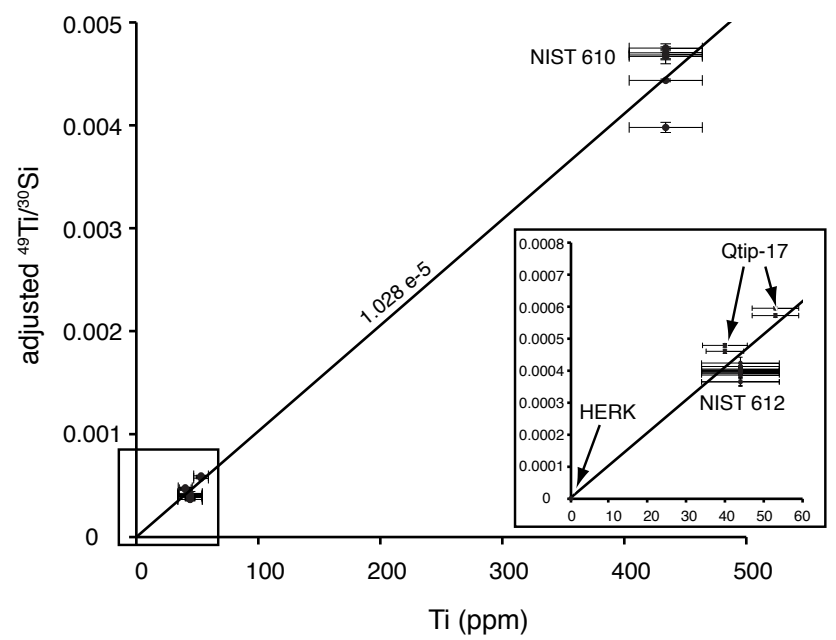

Fig. 5. Ti content of standards vs. adjusted ${ }^{49} \mathrm{Ti} /{ }^{30} \mathrm{Si}$ ratios. Measured ${ }^{49} \mathrm{Ti} /{ }^{30} \mathrm{Si}$ ratios for NIST glasses are corrected for Si concentration (multiplied by factors of 0.7 and 0.72 for NIST 610 and 612 , respectively, to account for differences in silica content between quartz and NIST glass) then divided by a correction factor of 0.67 (Behr et al., 2010) to enable direct comparison with quartz standards. The plotted regression line is constrained by the origin and data for NIST glasses only. Quartz samples Qtip-17 and a sample of Herkimer "Diamond" are plotted for comparison purposes (see text). Error bars for ${ }^{49} \mathrm{Ti} /{ }^{30} \mathrm{Si}$ ratios and $\mathrm{Ti}$ concentrations are $2 \sigma$.

reproducibility using the same glasses and quartz standards on the SIMS at Arizona State University (W. Behr, personal communication, 2011). To check the Behr et al. (2010) correction factor, in our third analytical session we analysed an experimentally synthesized, Ti-doped quartz (sample "Qtip 17" from Thomas et al., 2010) which has light and dark sector zones in CL images and independently known Ti concentrations of $53 \pm 3$ and $40 \pm 2 \mathrm{ppm}$, respectively. We measured similar Ti concentrations of $56.0 \pm 1$ and $47.6 \pm 1 \mathrm{ppm}$, respectively, using the NIST glass as standards. A regression line based on these results instead of the NIST glasses would shift our results only $\sim 10^{\circ} \mathrm{C}$ lower. As a Ti-blank, we used Herkimer "Diamond," a natural quartz containing $<6 \mathrm{ppb}$ Ti (Kohn and Northrup, 2009). Our analyses of this natural blank gave apparent concentrations of $15 \pm 20$ and $31 \pm 42 \mathrm{ppb}$ in session 1 . The higher beam current used in later sessions however allowed us to resolve an apparent concentration of $\sim 4-5 \pm 2 \mathrm{ppb}$ in the blank, consistent with previous work (Kohn and Northrup, 2009). No blank correction was made since these values are minimal and consistent with the expected Ti concentration of Herkimer diamond estimated by Kohn and Northrup (2009).

The TitaniQ calibration of Wark and Watson (2006) was based on experiments carried out at a uniform pressure of $10 \mathrm{kbar}$. Later experiments by Thomas et al. (2010) found a significant pressure dependence captured by the expression 
$\mathrm{RT} \ln X_{\mathrm{TiO}_{2}}^{\mathrm{quartz}}=-60952+1520 \times T(K)$

$-1741 \times P(\mathrm{kbar})+\mathrm{RT} \ln a_{\mathrm{TiO}_{2}}$

where $R$ is the gas constant $8.3145 \mathrm{~J} / \mathrm{K}, T$ is temperature in Kelvin, $X_{\mathrm{TiO}_{2}}^{\text {quartz }}$ is the mole fraction of $\mathrm{TiO}_{2}$ in quartz, and $a_{\mathrm{TiO}_{2}}$ is the activity of $\mathrm{TiO}_{2}$ in the system. Huang and Audétat (2012) found that Ti concentrations in experimentally grown quartz additionally correlate with the crystallization rate, and present the relationship

$$
\begin{aligned}
\log \operatorname{Ti}(\mathrm{ppm})= & -2794.3 / T-660.53 \\
& \times\left(P^{0.35} / T\right)+5.6459
\end{aligned}
$$

based on their slowest experiments, with $T$ given in Kelvin and $P$ in kbar. Unless otherwise noted, TitaniQ temperatures reported in the paper are based on the Thomas et al. (2010) calibration.

Because metamorphic mineral assemblages observed in the Hsüehshan range are not amenable to independent quantitative geobarometry (Beyssac et al., 2007), we assume that pressure and temperature for each analysis are linked by a geothermal gradient of $25 \pm 5^{\circ} \mathrm{km}^{-1}\left(91^{\circ} \mathrm{kbar}^{-1}\right.$ assuming a crustal density of $2.8 \mathrm{~g} \mathrm{~cm}^{-3}$ ). This geothermal gradient is broadly consistent with the change of $25-30^{\circ} \mathrm{km}^{-1}$ in RSCM temperature with stratigraphic depth in the study area (Beyssac et al., 2007), the thermal history modeled by Simoes et al. (2007) for deep exposures of the Hsüehshan range prior to $4 \mathrm{Ma}$ (Fig. 6), and the average thermal gradient in exploration wells in Taiwan (Zhou et al., 2003). The uncertainty in the estimate of the geothermal gradient of +5 or $-5^{\circ} \mathrm{km}^{-1}$ would alter a temperature estimate of $\sim 300^{\circ} \mathrm{C}$ by -10 or $+17^{\circ} \mathrm{C}$, respectively (Fig. 6). We used a Ti activity of 1.0 since the quartzites, wall rocks of veins, and some veins themselves contain rutile.

Data for samples and standards are reported in a Supplement. We averaged Ti concentrations based on ${ }^{47} \mathrm{Ti} /{ }^{30} \mathrm{Si}$ and ${ }^{49} \mathrm{Ti} /{ }^{30} \mathrm{Si}$ measurements to calculate reported temperatures (the average ${ }^{47} \mathrm{Ti} /{ }^{49} \mathrm{Ti}$ of all the data is $1.37 \pm 0.01$, within error of natural occurrence $1.375 \pm 0.006$; De Laeter et al., 2003). The uncertainties in temperature and pressure given for each analysis in the Supplement are dominated by analytical precision, but also include negligible uncertainties related to analyses of standards and the above mentioned correction factor of Behr et al. (2010). Median temperatures for recrystallized quartzite, unrecrystallized veins, and recrystallized veins are given in Table 1 . The " $1 \sigma$ " and standard errors given in Table 1 reflect only the standard deviation of the pooled analyses for a given vein or recrystallized fraction. Systematic errors resulting from uncertainty in the TitaniQ calibration and the geotherm estimate are also given in Table 1. By "fully recrystallized" we refer to areas with a fairly uniform recrystallized grain size, i.e. places where the beam intersected only unambiguously new grains with clear grain boundaries (no subgrains). Sorting of unrecrystallized

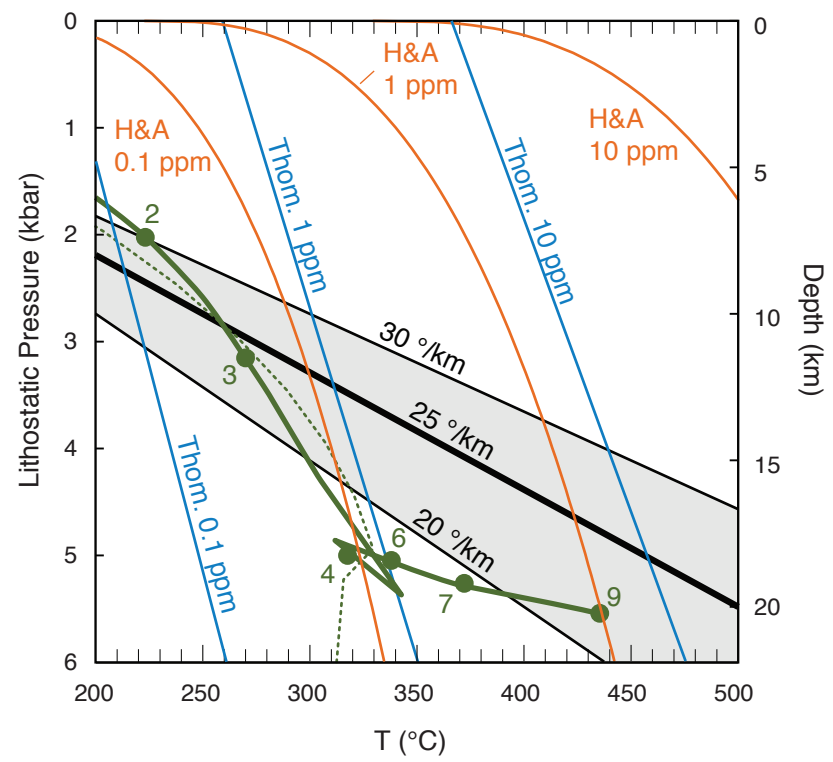

Fig. 6. Pressure-temperature plot showing the Thomas et al. (2010) and Huang and Audétat (2012) TitaniQ calibrations for $0.1,1$, and $10 \mathrm{ppm} \mathrm{Ti}$; the $25^{\circ} \mathrm{km}^{-1}$ geothermal gradient assumed in our calculations with $\pm 5^{\circ} \mathrm{km}^{-1}$ uncertainty (grey field); the PT path for the core of the Hsüehshan range from the model of Simoes et al. (2007) (solid green line) with numbers indicating ages in Ma. The geothermal gradient at $4 \mathrm{Ma}$ from the thermokinematic model of Simoes et al. (2007) is shown as a dotted green line.

and recrystallized quartz analyses was done under the petrographic microscope following SIMS analyses but without knowledge of the Ti content of the spots.

Cathodoluminescence (CL) images were acquired on a Zeiss 1550 VP field emission scanning electron microscope at Caltech. Photons were collected using a variable-pressure secondary electron (VPSE) detector operated at high vacuum, $30 \mathrm{kV}$ accelerating voltage and $7 \mathrm{nA}$ beam current. The detector is sensitive in the range $300-650 \mathrm{~nm}$. Based on previous observations that $\mathrm{Ti}$ concentration is linked to blue $\mathrm{CL}$ wavelengths (ca $415 \mathrm{~nm}$ ), we also collected several CL images using a $415 \mathrm{~nm}$ bandpass filter and a filter that removes signals > $\sim 500 \mathrm{~nm}$ (Rosco R381, "Baldassari Blue"). The filters were mounted on the end of the VPSE detector. Qualitative measures of CL intensity were made in image analysis software by averaging CL intensity in a $10 \mu \mathrm{m}$ circle centred on analysed SIMS spots.

\section{Rock descriptions}

\subsection{Veins}

Studied quartz veins are generally $>99 \%$ quartz with rare fragments of wall rock, chlorite, carbonate, illmenite, rutile, fluid inclusions, and pressure solution seams. The wall rock of all the veins contains rutile; the presence or absence of 
Table 1. Summary of results. Abbreviations: ms (metasiltstone), q (quartzite), s (slate), $1 \sigma$ (random error), SE ( $1 \sigma$ standard error), Rxl (recrystallization), sys. err. (systematic error due to uncertainty in the geotherm and TitaniQ calibration). Asterisks (*) indicate veins constrained by crosscutting relationship to have emplacement temperatures $>250{ }^{\circ} \mathrm{C}$.

\begin{tabular}{|c|c|c|c|c|c|c|c|c|c|c|c|c|c|c|c|c|c|c|}
\hline $\begin{array}{l}\text { Sample/ } \\
\text { sample } \\
\text { area }\end{array}$ & $\begin{array}{l}\text { Vein } \\
\text { type }\end{array}$ & $\begin{array}{l}\text { Rutile } \\
\text { in } \\
\text { vein? }\end{array}$ & Host & $\begin{array}{l}\text { Width } \\
(\mathrm{mm})\end{array}$ & $\begin{array}{c}\mathrm{Ti}(\mathrm{ppm}) \\
\text { median }\end{array}$ & $\begin{array}{c}\text { Mean } \\
\text { vein } T \\
\left({ }^{\circ} \mathrm{C}\right)\end{array}$ & $\begin{array}{c}\text { Median } \\
\text { vein } T \\
\left({ }^{\circ} \mathrm{C}\right)\end{array}$ & $1 \sigma$ & $\begin{array}{l}\text { Sys. } \\
\text { err. }\end{array}$ & $\mathrm{N}$ & SE & $\begin{array}{l}\text { Rxl qtz Ti } \\
(\mathrm{ppm}) \\
\text { median }\end{array}$ & $\begin{array}{l}\text { Rxl } T \\
\left({ }^{\circ} \mathrm{C}\right) \\
\text { mean }\end{array}$ & $\begin{array}{c}\text { Rxl } T \\
\left({ }^{\circ} \mathrm{C}\right) \\
\text { median }\end{array}$ & $1 \sigma$ & $\begin{array}{l}\text { Sys. } \\
\text { err. }\end{array}$ & $\mathrm{N}$ & SE \\
\hline $004 / 2$ & $\mathrm{D}$ & $\mathrm{n}$ & $\mathrm{ms}$ & 0.5 & 0.32 & 265 & 258 & 17.7 & 27.2 & 7 & 6.7 & - & - & - & - & - & - & - \\
\hline $004 / 2$ & $\mathrm{D}^{*}$ & $\mathrm{y}$ & $\mathrm{ms}$ & 0.5 & 0.19 & 238 & 237 & 5.6 & 26 & 5 & 2.5 & - & - & - & - & - & - & - \\
\hline $004 / 34$ & $\mathrm{D}$ & $\mathrm{y}$ & $\mathrm{ms}$ & 2 & 0.48 & 286 & 276 & 38.1 & 28.1 & 16 & 9.5 & 0.88 & 306 & 305 & 52 & 30 & 8 & 18.5 \\
\hline $004 / 34$ & $\mathrm{D}^{*}$ & $\mathrm{y}$ & $\mathrm{ms}$ & 0.5 & 0.52 & 279 & 279 & 14.3 & 28.3 & 10 & 4.5 & - & - & - & - & - & - & - \\
\hline $004 / 5$ & $\mathrm{D}$ & $\mathrm{n}$ & $\mathrm{ms}$ & 1 & 0.59 & 282 & 286 & 28.7 & 28.6 & 5 & 13 & - & - & - & - & - & - & - \\
\hline $004 / 5$ & $\mathrm{D}^{*}$ & $\mathrm{n}$ & $\mathrm{ms}$ & 0.1 & 0.38 & 272 & 265 & 29.7 & 27.5 & 11 & 9 & - & - & - & - & - & - & - \\
\hline 005 & A & $\mathrm{y}$ & $\mathrm{q}$ & 5 & 0.54 & 309 & 282 & 77.6 & 28.4 & 6 & 32 & 0.44 & 276 & 272 & 13 & 28 & 6 & 5 \\
\hline $111 \mathrm{~b} / 1$ & $\mathrm{E}$ & $\mathrm{n}$ & $\mathrm{q}$ & 1.1 & 0.31 & 256 & 257 & 14.1 & 27.1 & 9 & 4.7 & 0.28 & 253 & 252 & 8 & 27 & 6 & 3.4 \\
\hline $111 \mathrm{~b} / 2$ & $\mathrm{E}$ & $\mathrm{n}$ & $\mathrm{q}$ & 5 & 1.12 & 313 & 317 & 17.1 & 30.4 & 5 & 7.6 & - & - & - & - & - & - & - \\
\hline $123 b$ & B & $\mathrm{y}$ & $\mathrm{s}$ & 4 & 0.30 & 260 & 256 & 14.5 & 27 & 10 & 4.6 & 0.43 & 272 & 271 & 21 & 28 & 14 & 5.5 \\
\hline $123 b$ & $\mathrm{C}^{*}$ & $\mathrm{n}$ & $\mathrm{s}$ & 25 & 0.81 & 303 & 300 & 39 & 29.5 & 9 & 13 & - & - & - & - & - & - & - \\
\hline $123 \mathrm{c}$ & $\mathrm{E}$ & $\mathrm{n}$ & $q$ & $>10$ & 0.49 & 284 & 277 & 29.7 & 28.2 & 7 & 11 & 0.52 & 279 & 279 & 2 & 28 & 2 & 1.1 \\
\hline $131 \mathrm{~g}$ & $\mathrm{D}$ & $\mathrm{n}$ & $q$ & 3.6 & 0.57 & 285 & 284 & 12.2 & 28.5 & 8 & 4.3 & 0.66 & 293 & 291 & 7 & 29 & 9 & 2.4 \\
\hline $148 \mathrm{~d}$ & - & - & - & - & - & - & - & - & - & - & - & 1.60 & 366 & 336 & 70 & 32 & 35 & 11.7 \\
\hline $148 \mathrm{j}$ & - & - & - & - & - & - & - & - & - & - & - & 1.83 & 379 & 344 & 67 & 32 & 13 & 18.4 \\
\hline $148 \mathrm{j}$ & A & $\mathrm{y}$ & $q$ & $1 \& 9$ & 0.72 & 330 & 295 & 93.3 & 29.2 & 28 & 18 & 1.24 & 322 & 322 & 24 & 31 & 9 & 8.0 \\
\hline
\end{tabular}

rutile in veins is indicated in Table 1 . The veins were collected from slate, metasiltstone, and fine- to coarse-grained quartzites, and have thicknesses ranging from $100 \mu \mathrm{m}$ to $25 \mathrm{~mm}$ (Table 1). Five types of veins were sampled: Type A veins are bedding-perpendicular veins with NNW to NE strikes (i.e. roughly perpendicular to modern plate convergence) when bedding is restored to horizontal. Tillman et al. (1992) noted that these veins are overprinted by compression-related faults, folds, and cleavage and assigned them a "pre-collisional" extensional origin. Type B veins are heavily deformed veins found in slates with orientations subparallel to foliation. Type B veins could have pre- or early syn-collisional emplacement ages. Type $\mathrm{C}$ veins crosscut foliation and clearly post-date most of the collisional deformation associated with cleavage formation. Type $\mathrm{D}$ veins are concentrated within the hinge zones of map-scale folds (e.g. Fig. 3). Type C and D veins were emplaced during collision. Type $\mathrm{E}$ veins are veins of uncertain origin found in quartzite. All of the analysed veins are dynamically recrystallized.

\subsection{Quartzites}

Two quartzite samples (148d and 148j) were chosen for intensive analysis. They have a wide range of initial grain size: fine-grained layers have detrital grains as small as $100 \mu \mathrm{m}$, while coarser layers contain grains commonly as large as $3 \mathrm{~mm}$. The quartzite contains $\sim 60 \%-80 \%$ quartz (detrital grains of quartz, quartzite, chert and quartz schist), along with lithic fragments (predominantly volcanics and slate), detrital feldspar and mica, and metamorphic chlorite and biotite (Figs. 7 and 8). The quartzites are moderately deformed with a minimum axial strain of 0.32 (Kidder et al., 2012). Bedding perpendicular foliation in the quartzites is defined by the near-vertical, NNE-SSW elongated orientation of flattened porphyroclasts and subgrains (Figs. 2 and 7). This fabric is indistinguishable in orientation from the collisional fabrics in neighboring slates (figure 2; Clark et al., 1993; Tillman and Byrne, 1995; Fisher et al., 2002).

\subsection{Dynamic recrystallization}

Throughout the Hsüehshan range, quartzites and quartz veins are dynamically recrystallized with a fine grain size of 4$22 \mu \mathrm{m}$ (e.g. Figs. 9 and 10; Kidder et al., 2012). This recrystallization is focused along grain boundaries and occupies only $5 \%-10 \%$ of the samples, allowing at least rough outlines of original detrital grains to be established in thin sections (e.g. Fig. 11). Porphyroclasts (remnants of both detrital quartz grains and coarse vein quartz grains) are irregularly flattened, have serrated grain boundaries, strong undulose extinction, contain irregular subgrains of variable size, and contain rare deformation lamellae (Figs. 9-13). These features indicate a classification in the low temperature "bulge" recrystallization regime (Stipp et al., 2002a; Stipp et al., 2010), a rough analogue to the experimental dislocation creep "regime 1" of Hirth and Tullis (1992).

In the core of the Hsüehshan range, the bulging recrystallization is the latest phase of dynamic recrystallization and overprints coarser recrystallized grains $(\sim 100-200 \mu \mathrm{m})$, which we refer to as "mid-sized" grains. The mid-sized grains (and subgrains of similar size) have a strong oblate shape preferred orientation with long axes parallel to foliation (Figs. 7, 10, 12). While compressional deformation is clearly responsible for the shape preferred orientation of the mid-sized grains, a post-depositional origin for a significant fraction of these grains is established by comparison with undeformed Tachien and Paileng quartzites to the east and west 

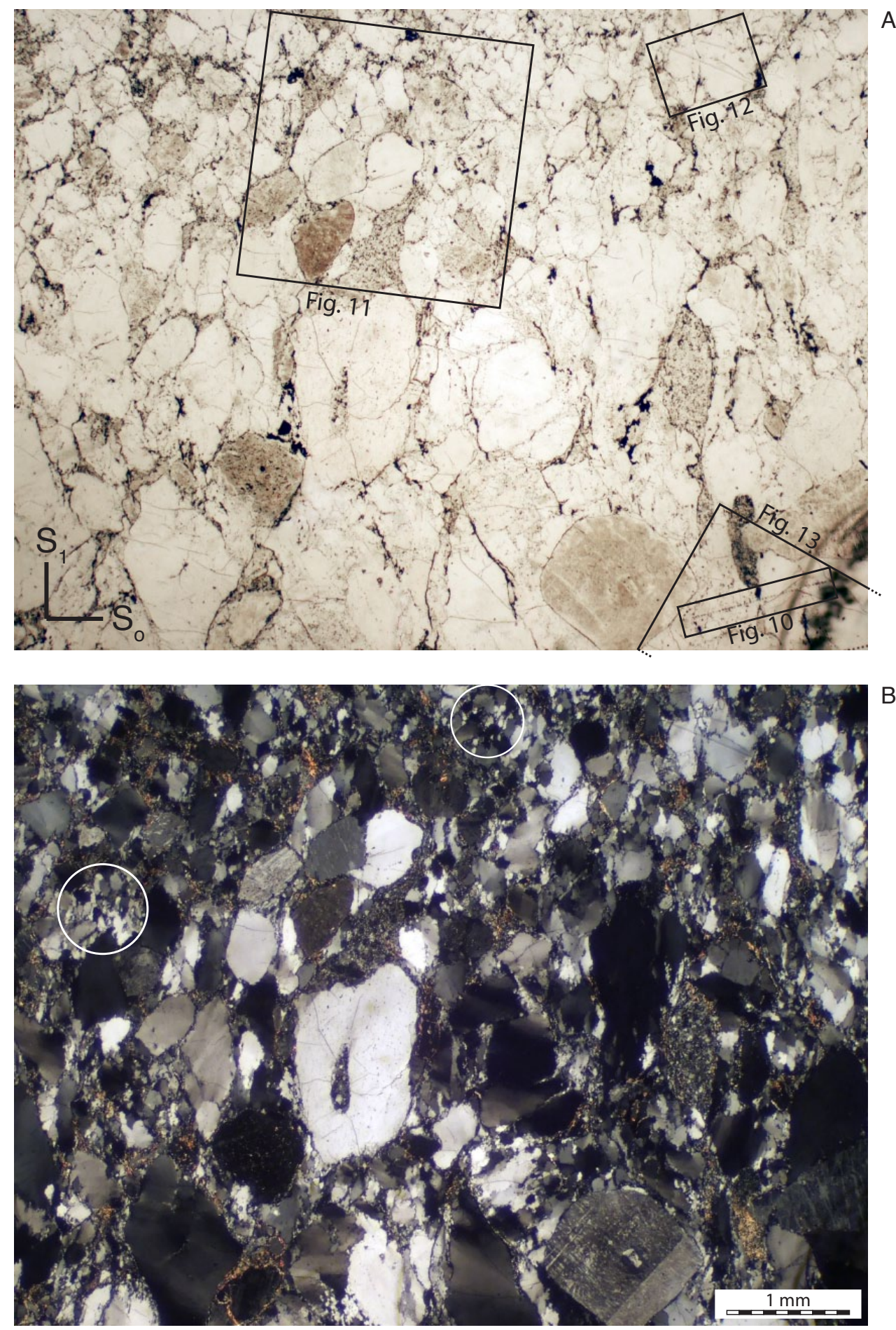

Fig. 7. Photomicrographs of sample 148d oriented with bedding horizontal and vertical tectonic foliation marked by preferred orientation of porphyroclasts and subgrains. (A) Unpolarized. (B) Cross-polarized. The white circles in (B) indicate two (of many) locations populated by "mid-sized" grains we interpret to have formed during early compressional deformation. 


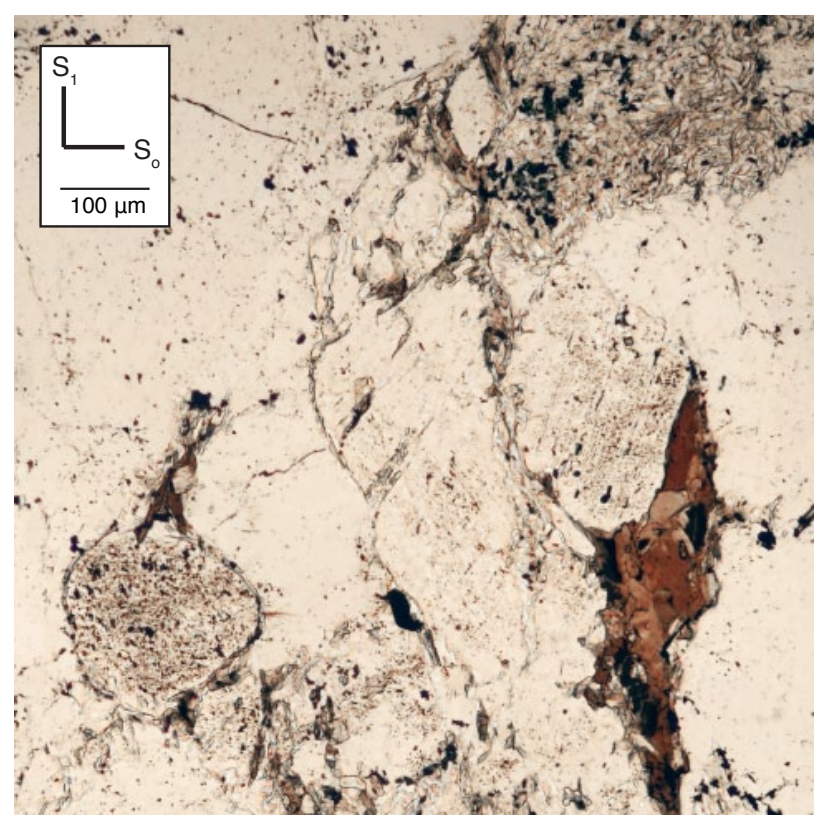

Fig. 8. Photomicrograph of sample 148d showing growth of metamorphic biotite in strain fringes on two detrital feldspar grains in the core of the Tachien anticline. Bedding and tectonic shortening direction (WNW-ESE) are horizontal in the figure.

of the Tachien anticline. In these rocks it is clear that the detrital source region had relatively few quartzites with this recrystallized grain size fraction (Fig. 11a, b). The size of the mid-sized grains falls at the boundary between recrystallized grains interpreted to have formed by subgrain rotation recrystallization and grain boundary migration recrystallization (Stipp et al., 2010). It is likely that both processes were active since subgrains are abundant with similar size and orientation as fully recrystallized mid-sized grains (e.g. Fig. 11), and petrographic evidence for migration of grain boundaries at a scale of 50-60 $\mu \mathrm{m}$ across interpreted detrital boundaries is also common (Fig. 12).

\section{Results}

\subsection{Independent constraints on temperature}

The grey field shown in Fig. 2c depicts the range indicated by independent constraints on temperature for dynamic recrystallization. In the case of samples $148 \mathrm{~d}$ and $148 \mathrm{j}$, this field brackets the formation of the fine recrystallized grains overprinting the mid-sized grains discussed above.

\subsubsection{Minimum and maximum temperature constraints}

Raman spectroscopy of carbonaceous material (RSCM) analyses (Beyssac et al., 2007) reflect peak temperature conditions and therefore serve as maximum temperature con- straints for deformation. The spatial distribution of RSCM data from Beyssac et al. (2007) is plotted as grey diamonds in Fig. 2c. Systematic ("calibration") error associated with RSCM is $\sim \pm 50^{\circ} \mathrm{C}$ (Beyssac et al., 2004). The formation of dynamically recrystallized quartz grains requires a minimum temperature of $250-300^{\circ} \mathrm{C}$ (Voll, 1976; Dresen et al., 1997; Dunlap et al., 1997; Stöckhert et al., 1999; van Daalen et al., 1999; Stipp et al., 2002a).

\subsubsection{Structural constraints on vein emplacement temperature}

Structural observations indicate that eight of the analysed veins (types $\mathrm{C}$ and $\mathrm{D}$ ) were emplaced at temperatures above those required for dynamic recrystallization (i.e. $>250$ $300^{\circ} \mathrm{C}$ ). The other six veins (types A, B, and E) have only maximum emplacement temperatures constrained by RSCM. Temperature constraints for the type $\mathrm{C}$ and $\mathrm{D}$ veins are based on the observation that the Hsüehshan range was at or near peak temperatures at the onset of collision and followed a relatively monotonic cooling path thereafter (Fig. 4). Since these (dynamically recrystallized) veins formed during collision but prior to cooling below temperatures at which dynamic recrystallization does not occur, these veins have emplacement temperatures $>250{ }^{\circ} \mathrm{C}$.

In some cases, crosscutting relationships are used to indicate vein emplacement at temperatures $>250^{\circ} \mathrm{C}$. In these cases, a vein with relatively minor dynamic recrystallization crosscuts an earlier, more strongly deformed vein (e.g. Fig. 9). Since temperatures were $>250{ }^{\circ} \mathrm{C}$ both before and after emplacement of the crosscutting vein, we conclude that emplacement of the crosscutting veins also occurred above $250^{\circ} \mathrm{C}$. These crosscutting veins are indicated by an asterisk in Table 1 and Fig. 14.

\subsubsection{Microfabric constraints on maximum deformation temperature}

An additional constraint on deformation temperature can be derived using the quartz deformation mechanism map of Stipp et al. (2002b). The map links the transitions between the three laboratory-based dislocation creep regimes in quartz (Hirth and Tullis, 1992) with similar microstructures found in well-constrained natural settings, and delineates boundaries in temperature-strain rate space between the regimes. Maximum bulk strain rate in the quartzite samples was $\sim 7.0 \times 10^{-14} \mathrm{~s}^{-1}$ (Kidder et al., 2012), yielding a maximum likely temperature for bulging recrystallization of $\sim 360^{\circ} \mathrm{C}$. Uncertainties associated with this approach are significant but unquantified; we assume a value of $\pm 50^{\circ} \mathrm{C}$ in Fig. 2c (i.e. the upper limit of the grey field is drawn at $\left.410^{\circ} \mathrm{C}\right)$. 

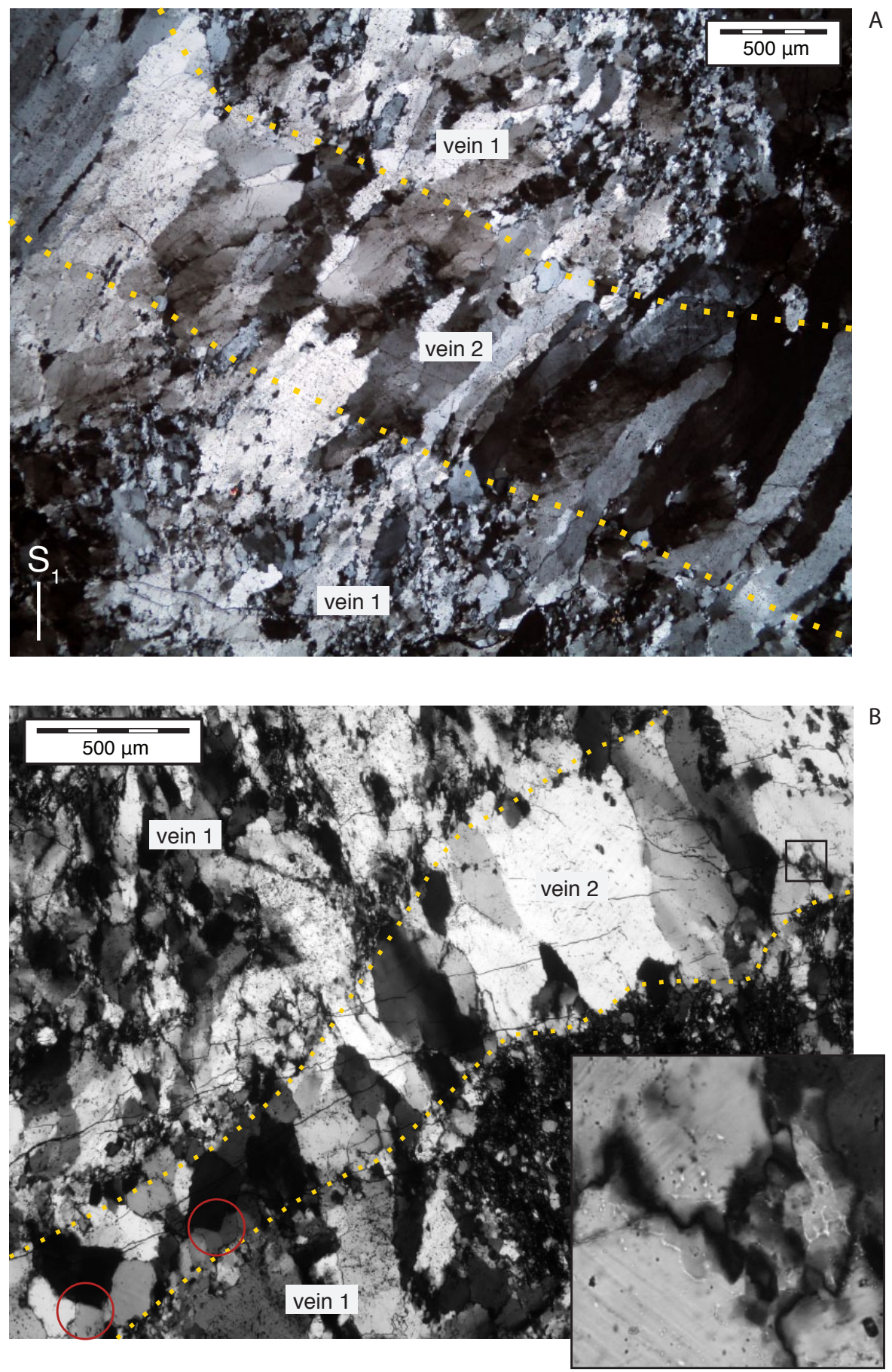

Fig. 9. Crosscutting relationships indicating vein emplacement at temperatures where dynamic recrystallization is active $\left(>250{ }^{\circ} \mathrm{C}\right)$. $(\mathrm{A})$ Photomicrograph of sample 123b, a slate, showing a strongly recrystallized type B vein ("vein 1") cut by a later type C vein ("vein 2 ") outlined in yellow. The early vein was likely transposed to its present orientation parallel to subvertical foliation (foliation not visible in the image). A minimum emplacement temperature for the older vein is unknown, however vein 2 cuts the recrystallized, compressional fabric but also shows evidence of dislocation creep (e.g. serrated boundaries of grains). Given this evidence of temperatures $>250{ }^{\circ} \mathrm{C}$ both before and after emplacement of vein 2, and the monotonic cooling history of the Hsüehshan range (Fig. 4), vein 2 emplacement occurred above $250^{\circ}$ C. (B) Photomicrograph of veins from the core of an anticline (site 34 in sample 004), with early vein material strongly recrystallized in the upper left part of the photograph. Emplacement of a late vein ("vein 2") running from lower left to upper right postdates much of the dynamic recrystallization of the earlier vein. The late vein has a lower inclusion concentration and retains some crystal facets (red circles). Undulatory extinction, subgrains, and minor dynamic recrystallization (inset) of the late vein indicate it too was deformed at temperatures $>250^{\circ} \mathrm{C}$. Vein emplacement was thus also at temperatures $>250{ }^{\circ} \mathrm{C}$ for the same reasons given for (A). 

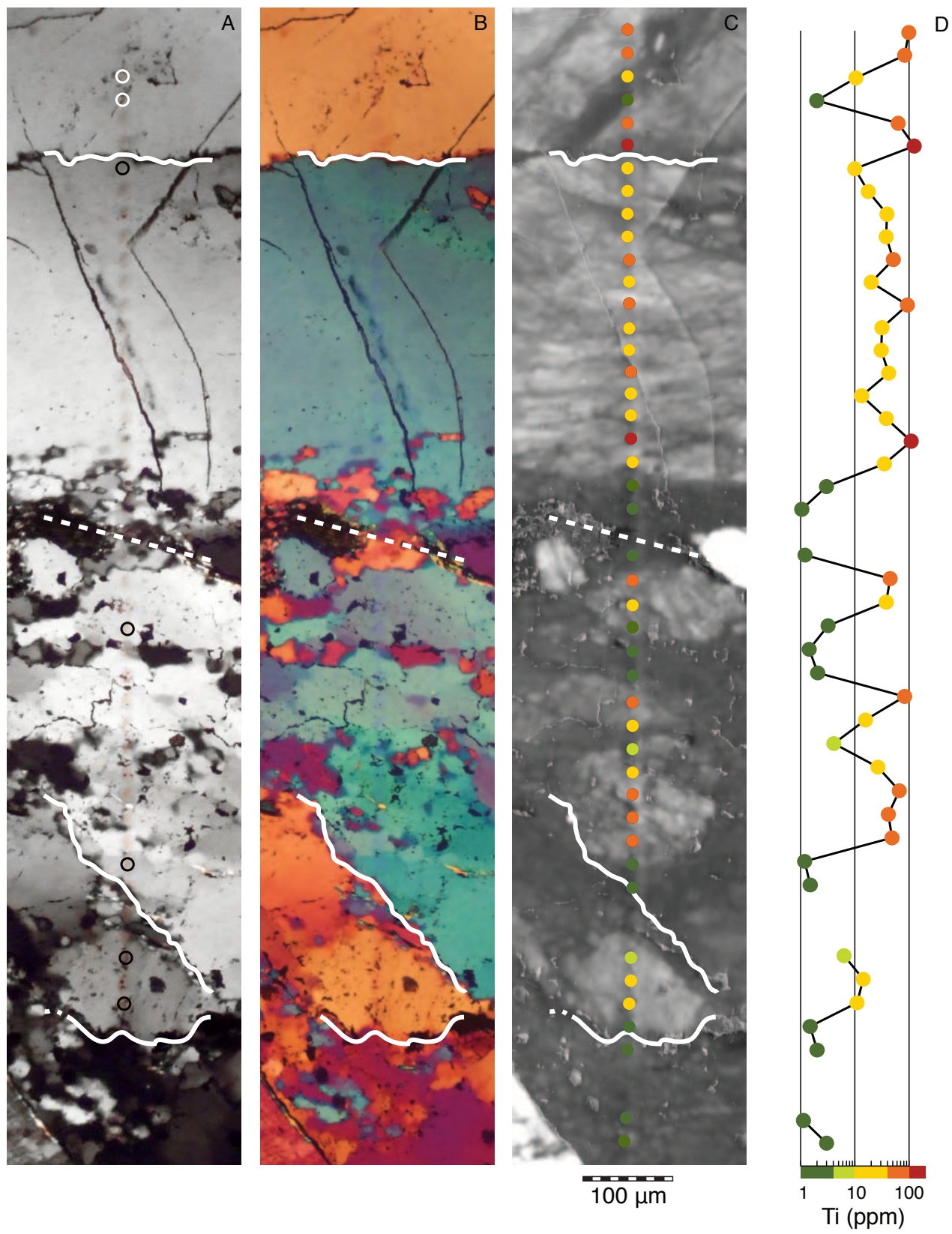

Fig. 10. Cross-polarized photomicrograph (A), cross-polarized photomicrograph with mica-plate inserted (B), and full-spectrum (300$650 \mathrm{~nm}$ ) CL image (C) of the same area of quartzite sample 148d. (D) Graph of Ti concentrations for SIMS analyses. White lines on the images are detrital grain boundaries. The five black-outlined spots in (A) are analyses where Ti concentration is notably reduced in the vicinity of grain boundaries. This trend does not hold for all grain boundaries (e.g. the edge of the top grain in the figure). Two white-outlined spots in the grain at the top of the figure show significant reduction of Ti content along a band marked by increased visible inclusions (A and $\mathbf{B}$ ) and lower CL intensity (C). This zone corresponds with a subgrain boundary visible under different polarization orientation. Areas recrystallized with a grain size of $\sim 10 \mu \mathrm{m}$ show lower Ti concentrations and darker CL.

\subsubsection{Flow law constraint on deformation temperature}

The late, overprinting dynamic recrystallization in the core of the Tachien anticline (quartzite samples 148d and 148j, grain size $\sim 13-15 \mu \mathrm{m}$ ) is coarser grained than in the region to the west where the vein samples were collected (grain size $\sim 7-12 \mu \mathrm{m}$, Kidder et al., 2012). The recrystallized grain size piezometer of Stipp and Tullis (2003) indicates differential stresses of $\sim 75 \mathrm{MPa}$ for the Tachien anticline quartzites and $\sim 110 \mathrm{MPa}$ for the western samples (Kidder et al., 2012). If we assume that quartzites in both regions were deformed at similar strain rates and that both deformed following a 

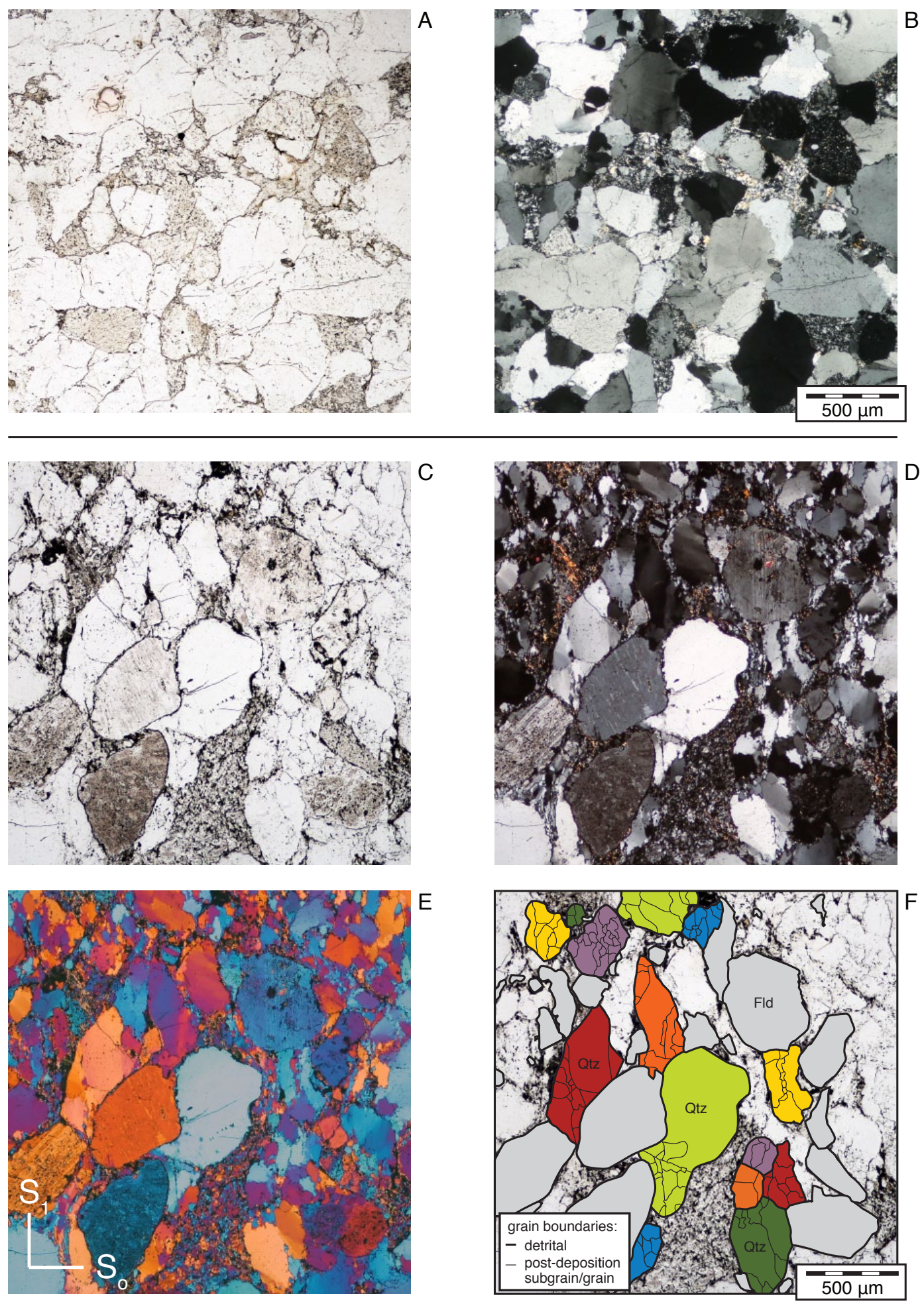

Fig. 11. Comparison of deformed and relatively undeformed Tachien sandstone. (A) Unpolarized and (B) Cross-polarized photomicrographs of relatively undeformed sample TQ15 (not oriented). (C) Unpolarized, (D) Cross-polarized, (E) Cross-polarized with mica-plate inserted, and (F) Microstructural interpretation of deformed sample 148d with examples of recrystallized detrital quartz grains shown in colour and feldspar grains shown in grey. The coloured detrital quartz grains in (F) contain numerous "mid-size" subgrains and recrystallized grains $(\sim 100-200 \mu \mathrm{m})$ interpreted to have formed post-depositionally since similar sized subgrains and recrystallized grains are not seen in undeformed samples, e.g. (B). A number of mid-sized grains of more ambiguous origin (sedimentary or recrystallized) are present in the upper right side of $(\mathbf{C}-\mathbf{F})$. Both types of mid-sized grains were analyzed in the study. Note that remnant gold coating in images $(\mathbf{C}-\mathbf{F})$ accentuates cracks and grain boundaries. 

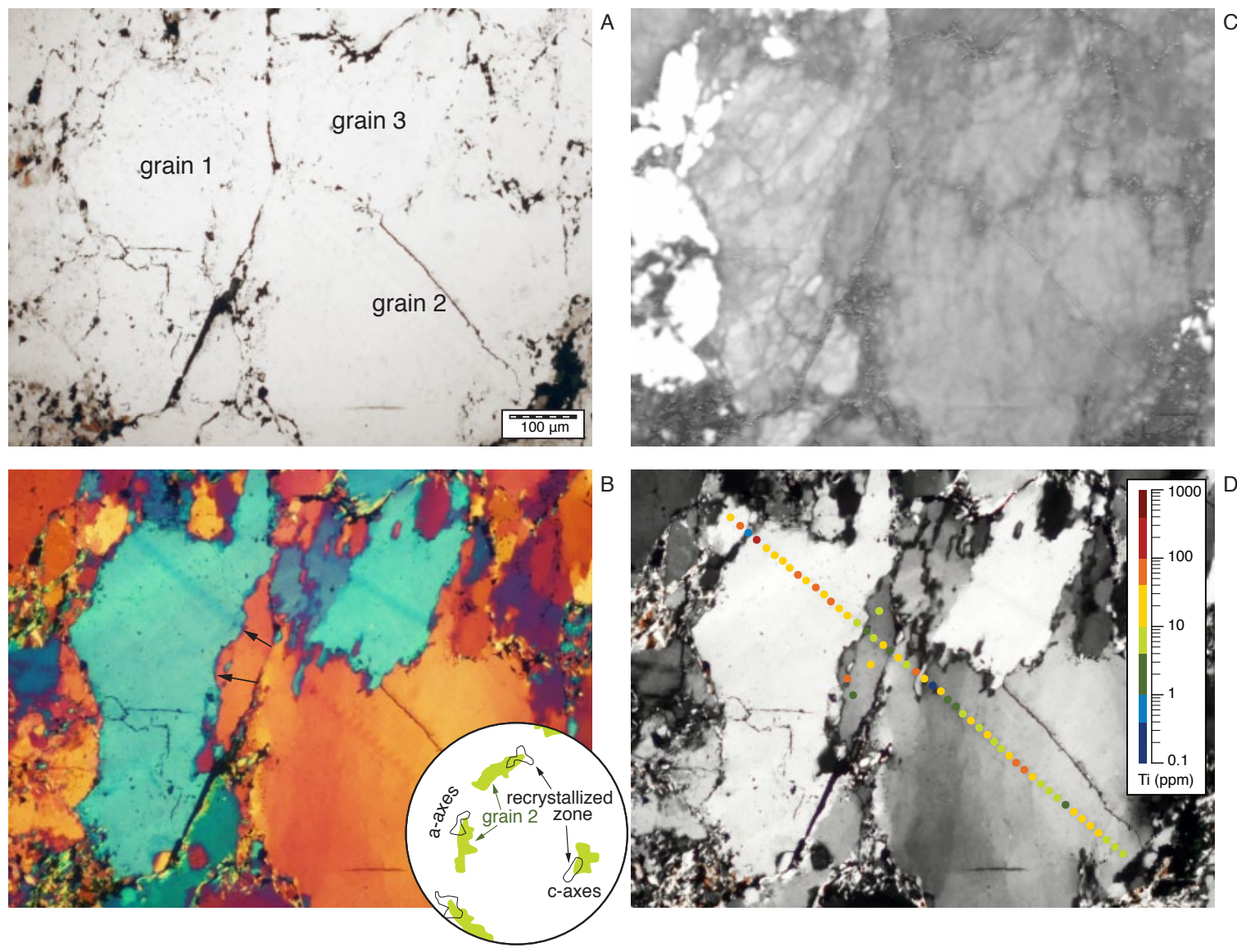

Fig. 12. Photomicrographs showing an example of a large-scale grain boundary migration. (A) Image taken in plain polarized light showing outlines of three labeled detrital grains. (B) Same image taken under cross-polarized light with mica-plate inserted. A portion of the right side of grain 1 has been recrystallized with the same orientation as grain 2. Arrows indicate the interpreted direction and magnitude of grain boundary migration. Inset stereonet shows orientation overlap of grain 2 (green) and overgrown area (black outlines) from electron backscatter diffraction. (C) Full-spectrum $(300-650 \mathrm{~nm}$ ) CL image of the same area. The recrystallized portion of grain 1 in this image has a slightly darker colour than either grain 1 or 2. (D) Cross-polarized image showing Ti concentrations in grains 1 and 2 . Ti concentrations in the recrystallized portion of grain 1 are significantly lower than the average Ti concentration of grain 1 (see text for details).

standard dislocation creep flow law, we can use the difference in differential stress between the two areas to estimate a temperature difference associated with the deformation. We estimate by this method that the Tachien anticline core was deformed at temperatures at least $50^{\circ} \mathrm{C}$ hotter than the western area using the flow law for quartzite of Hirth et al. (2001) and assuming equivalent water fugacity in the two areas. The estimate is a minimum because strain rates were probably slower in the west where the rocks show less penetrative strain (e.g. Fig. 11). Minimum deformation temperatures for samples $148 \mathrm{~d}$ and $148 \mathrm{j}$ were thus $\sim 300{ }^{\circ} \mathrm{C}$ (the minimum temperature of $250^{\circ} \mathrm{C}$ required for dynamic recrystallization, plus $50^{\circ} \mathrm{C}$ ).

\subsection{Ti concentrations}

\subsubsection{Veins}

Ti contents for each sampled vein are shown in Fig. 14 . Unrecrystallized portions of veins (unfilled bars in Fig. 14) have Ti concentrations of $\sim 0.2-1.0 \mathrm{ppm}$. Fully recrystallized vein quartz (filled bars in Fig. 14) have equivalent or slightly higher Ti concentrations, however in no sample is the difference in Ti concentration between recrystallized and primary vein quartz significant at a $2 \sigma$ level (Table 1 ).

\subsubsection{Quartzites}

A high density of analyses $(\mathrm{N}=459)$ in the two quartzite samples from the core of the Tachien anticline was designed to (1) establish potential differences in Ti concentration between undeformed remnant detrital grains and recrystallized 

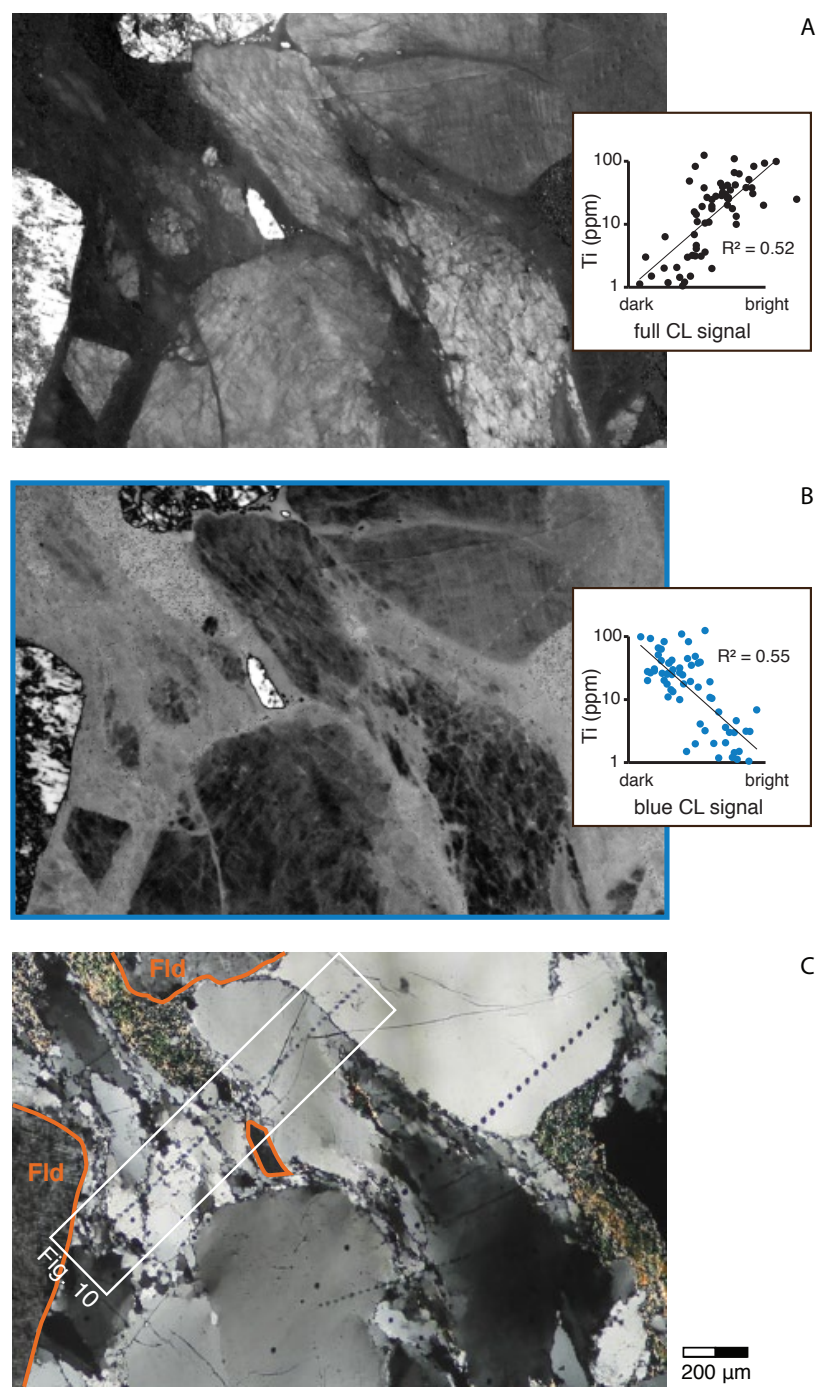

Fig. 13. CL images and plots of CL intensity vs. Ti concentration in deformed quartzite sample $148 \mathrm{~d}$. Ti concentration is positively correlated with broad-spectrum CL intensity and (contrary to the results of previous studies) inversely correlated with blue CL signal. (A) Full-spectrum (300-650 nm) CL image and full-spectrum CL intensity vs. Ti concentration from SIMS analyses showing moderate positive correlation. (B) Blue filtered CL image (300-500 nm) of same area and blue CL intensity vs. Ti concentration from SIMS transects. (C) Cross-polarized photomicrograph of same area with outlines of three feldspar grains ("Fld"). SIMS analyses are from the area shown in Fig. 10 and a second line in the lower right of the images.

grains (Figs. 10, 15, 16), (2) monitor potential changes in Ti concentration in quartz interpreted to have recrystallized via grain boundary migration (e.g. Figs. 12, 17), and (3) analyse quartz at various distances from the rims of porphyroclasts to document whether systematic changes in Ti content occur toward grain rims (Fig. 18). As shown in the histogram of detrital Ti concentrations in Fig. 15, unrecrystallized quartz shows a wide range of $\mathrm{Ti}$ concentrations from $\sim 0.1$ to $\sim 200 \mathrm{ppm}$ which we interpret, given slow diffusion rates of Ti in quartz (Cherniak et al., 2007), to reflect the diverse origins of the detrital quartz grains. Mid-sized grains have a range similar to the detrital grains (partly due to inclusion of some fine detrital grains in the mid-size fraction), but with a higher proportion of analyses in the range $\sim 1-10 \mathrm{ppm}$. Fully recrystallized grains $(\sim 10 \mu \mathrm{m})$ formed during the latest deformation phase peak in the range of $0.8-2 \mathrm{ppm}$ Ti (Fig. 15c).

\subsection{Cathodoluminescence (CL) and Ti concentration}

Previous authors have found a link between the intensity of CL signal and Ti-concentration in quartz (e.g. Rusk et al., 2008; Spear and Wark, 2009; Rusk et al., 2011). Wark and Spear (2005) showed that Ti concentration in a diverse set of quartz (hydrothermal, metamorphic, igneous, and synthetic) correlated with blue CL signal (ca. $415 \mathrm{~nm}$, see also Rusk et al., 2006). In full-spectrum (300-650 nm) CL images, we note a moderate correlation $\left(R^{2}=0.52\right)$ between CL intensity and Ti concentration (e.g. Figs. 10, 12, 13). CL intensity in quartz measured using a broad-spectrum blue filter however shows an inverted signal from the full-spectrum images (Fig. 13), with Ti concentration inversely correlated with CL intensity $\left(R^{2}=0.55\right)$. A similar first-order pattern between low CL intensity and high Ti concentration was observed using a $415 \mathrm{~nm}$ bandpass filter (see Supplement). These results indicate that the majority of the full-spectrum CL signal is in the wavelength range $500-650 \mathrm{~nm}$, and that Ti concentration in quartz does not always correlate with blue CL. We speculate that the difference in CL signal between the previously analysed quartz and the Taiwan quartzite is related to the presence of defects associated with deformation (e.g. Muto et al., 2005) in the Taiwan samples that are lacking in the undeformed or relatively undeformed samples analysed by Wark and Spear (2005).

\section{Discussion}

\subsection{Effect of dynamic recrystallization on $\mathrm{Ti}$ concentration in quartz}

Ti concentrations in quartz changed during recrystallization in the studied quartzites. Fine recrystallized grains mantling high Ti detrital quartz grains have lower Ti concentrations (Fig. 10). Early "mid-sized" recrystallized grains have modified Ti concentration distributions relative to detrital grains (Figs. 15, 16): only $20 \%$ of detrital grain analyses have intermediate Ti concentrations (1-15 ppm) while $45 \%$ of the Ti analyses of the mid-sized grains fall in this range (Fig. 15). It is clear from Fig. 16 that the trend towards intermediate Ti concentrations with reduced grain size continues to the finest grain fraction. 


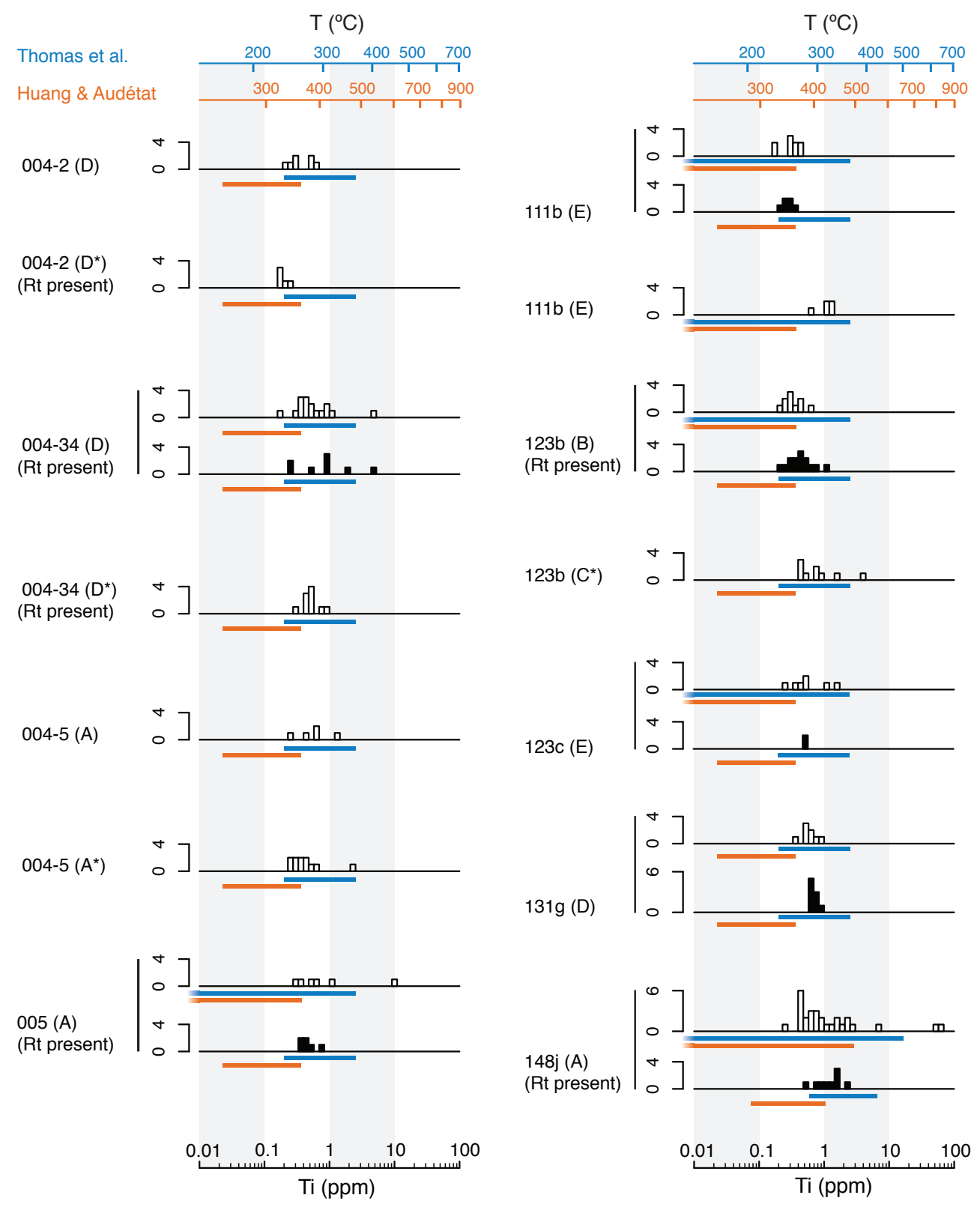

Fig. 14. Histograms showing Ti content of fully recrystallized (black fill) and unrecrystallized or incompletely recrystallized (white fill) vein quartz, and consistency between the Ti data and the Thomas et al. (2010) TitaniQ calibration. Orange and blue bars at the base of the histograms indicate the range of Ti concentrations predicted by the Huang and Audétat (2012) and Thomas et al. (2010) TitaniQ calibrations respectively based on independent PT constraints. The predicted Ti contents require assumptions about pressure (we estimate pressure using independently known temperatures and a $25^{\circ} \mathrm{km}^{-1}$ geothermal gradient, and assume here that the pressure term in the TitaniQ calibrations is lithostatic pressure). The temperature scales shown at the top of the figure are also plotted using these assumptions. Measured Ti values are in some cases significantly higher than predicted by the Huang and Audétat (2012) calibration. Letters in parenthesis indicate vein type (A-E). An asterisk (*) indicates an overprinting vein in a crosscutting relationship as shown, for example, in Fig. 9. Presence of rutile in veins is indicated (all host rocks contain rutile).

Do these changes represent equilibration of quartz and a Ti-bearing phase or phases? Or do they simply represent homogenization of quartz to an average composition, or incomplete loss of Ti from quartz without equilibration? The pattern of decreasing range of Ti-concentration with reduced grain size in Fig. 16 suggests that as recrystallization progressively reduced grain size, Ti-concentrations in quartz both decreased in areas that originally had high Ti-concentrations, and increased in areas that initially had low Ti-concentration. We conclude that Ti was not simply evacuated from quartz, 

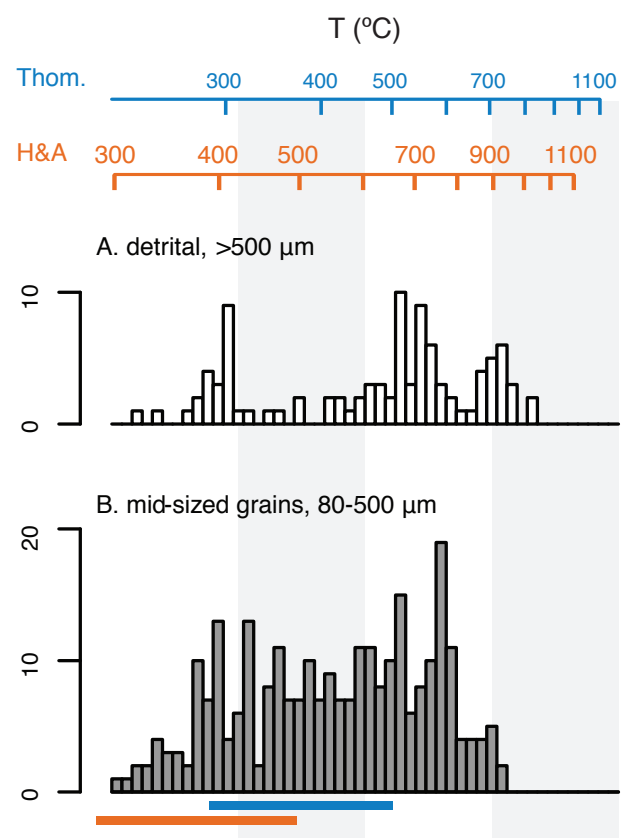

C. fully recrystallized, $\sim 10 \mu \mathrm{m}$

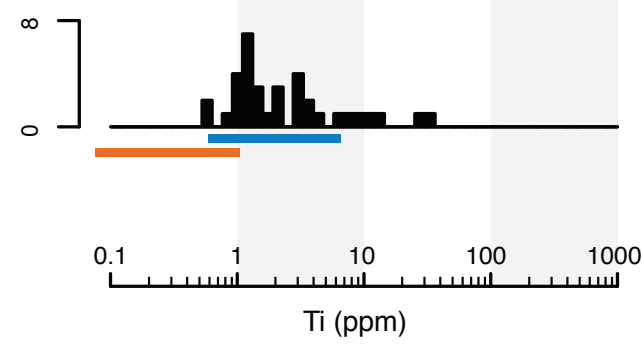

Fig. 15. Histograms for quartzites showing (A) Ti content of detrital grain remnants (white fill), (B) mid-sized grains of recrystallized and sedimentary origin (grey fill), and (C) fully recrystallized finegrained quartz (black fill). Orange and blue bars at the base of the histograms indicate the range of Ti concentrations predicted by the Huang and Audétat (2012) and Thomas et al. (2010) TitaniQ calibrations respectively as described in Fig. 14 caption. The histogram for detrital quartz is biased by the preferential analysis of low $\mathrm{Ti}$ grains, and its peaks should not be strictly interpreted in terms of sedimentary provenance. Figure (B) shows a marked increase in intermediate Ti concentration grains relative to $(\mathbf{A})$ indicating probable resetting of $\mathrm{Ti}$ in these grains. The restricted range of Ti concentrations in (C) relative to (A) and (B) suggests both gain and loss of Ti from parent quartz material (i.e. equilibration) during recrystallization. The Thomas et al. (2010) calibration provides better fit to the Ti data in $(\mathbf{B})$ and $(\mathbf{C})$.

but shifted toward an intermediate value. This value, $\sim 1-$ 2 ppm for the finest grain size fraction, is not simply an average concentration of initial Ti concentrations in detrital quartz grains, as we estimate a spatially averaged initial $\mathrm{Ti}$ concentration of the detrital grains was at least 10-20 ppm. We suggest that these changes in Ti concentration in recrys-

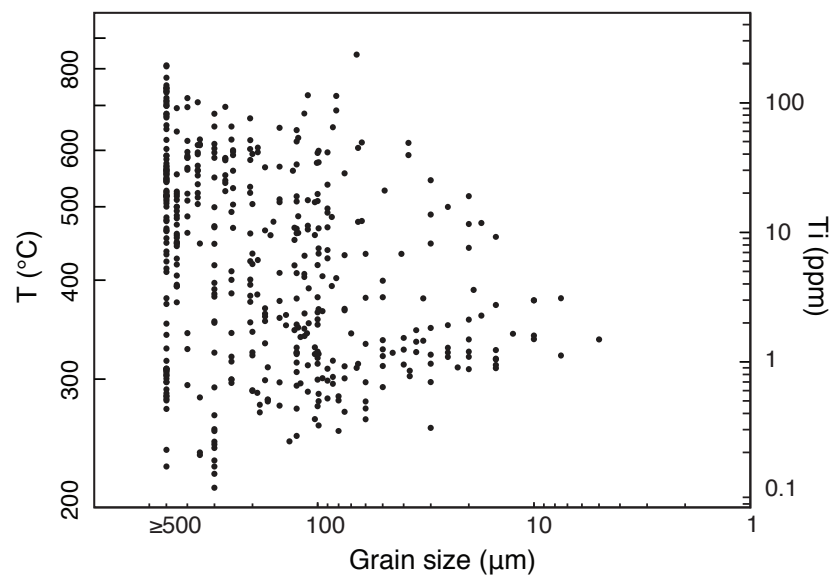

Fig. 16. Temperature vs. grain size for all analyses in the quartzite samples. The progressively restricted range of Ti concentrations at smaller grain sizes is interpreted to result from an increasing likelihood and extent of equilibration between quartz and Ti bearing phases as grain size decreased during dynamic recrystallization and cooling. Temperature scale shown is based on Thomas et al. (2010) and constructed as described in Fig. 14 caption.
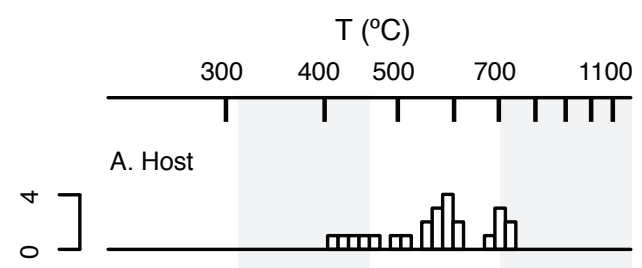

B. Area swept by GBM

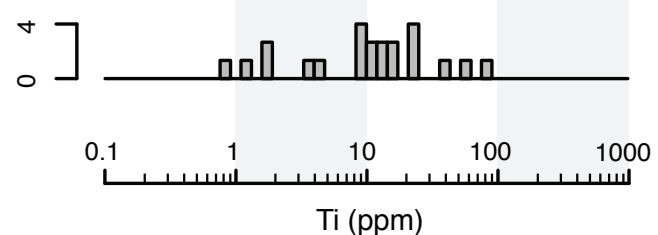

Fig. 17. Comparison of compiled Ti analyses in (A) six detrital porphyroclasts and $(\mathbf{B})$ regions of the same porphyroclasts believed to have recrystallized due to grain boundary migration (GBM). An example of one such site is shown in Fig. 12. The area affected by GBM shows reduced Ti concentration. Temperature scale shown is based on Thomas et al. (2010) and constructed as described in Fig. 14 caption.

tallized quartz reflect equilibration between quartz and at least one other phase.

In contrast to the quartzites, recrystallization of quartz in the studied veins was not associated with significant shifts in Ti concentration (Fig. 14). This may result from either a failure to reach equilibrium in the recrystallized veins or alternatively from vein emplacement and recrystallization occurring at similar PT conditions. 


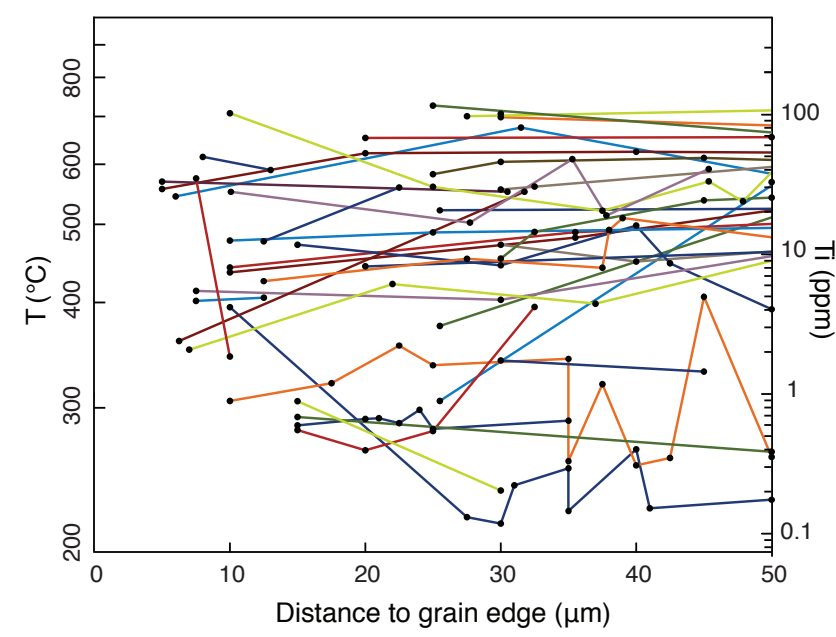

Fig. 18. Ti concentration vs. distance to grain edge in porphyroclasts. No systematic trend in Ti concentration is observed towards the edges of grains suggesting that bulk diffusion of Ti in quartz was not active to a significant extent. Temperature scale shown is based on Thomas et al. (2010) and constructed as described in Fig. 14 caption.

\subsection{Mechanisms of Ti mobility between grains and grain boundaries}

We suggest that changes in Ti concentration in quartz in the samples occurred predominantly during the migration of grain boundaries. During grain boundary migration, material is consumed along one side of a grain boundary and recrystallizes with a new orientation on the other side (e.g. Urai et al., 1986). This process provides the opportunity for exchange of trace elements between recrystallizing quartz and the grain boundary region. Grain boundary migration was clearly active in the quartzite samples as evidenced by the offset of crystallographic grain boundaries from interpreted detrital grain boundaries (as marked by opaque and nonquartz phases, see e.g. Fig. 12). Instances of such migration events are commonly observed petrographically, occurring in $\sim 10-20$ grains per thin section. Typical migration distances range up to $\sim 50 \mu \mathrm{m}$. Figure 12 demonstrates one such location where mean $\mathrm{Ti}$ concentration in an interpreted recrystallized area is $14 \pm 7 \mathrm{ppm}$ versus $34 \pm 2 \mathrm{ppm}$ Ti in the unrecrystallized host grain. Figure 17 compiles the results of six such sites where large-scale grain boundary migration is suspected. A shift to lower average Ti concentrations in the recrystallized areas is apparent. A similar conclusion was reached by Grujic (2011) who found reset Ti in mylonitized quartz veins recrystallized at temperatures above $\sim 540^{\circ} \mathrm{C}$.

Although predicted characteristic bulk diffusion distances for Ti in quartz based on experimentally-based diffusion coefficients (Cherniak et al., 2007) are exceedingly small under the deformation conditions experienced by the Hsüehshan range $\left(\sim 0.001 \mu \mathrm{m}\right.$ in $3.5 \mathrm{Myr}^{-1}$ at $\left.300^{\circ} \mathrm{C}\right)$, it is possible that diffusion processes could play a role in changing Ti concentrations (e.g. the effect of high dislocation densities and strain on diffusion in quartz is unknown). Such diffusion might be expressed by systematic, gradual shifts in Ti-concentration along grain rims. A few porphyroclasts show indications of such behaviour, e.g. the black-circled SIMS analyses in Fig. 10, and the slight convergence in Fig. 18 to intermediate Ti concentrations at distances of 5-20 $\mu \mathrm{m}$. While intriguing, these limited observations are insufficient to unequivocally point to diffusion, and we suggest that bulk diffusion of $\mathrm{Ti}$ was probably not a significant process in the studied samples.

While we find grain boundary migration a likely mechanism for resetting Ti in quartz in mid-sized grains, the fine grain size associated with the latest phase of deformation prevents a similar analysis of these grains. We note that the fine grains classify within the grain boundary bulging regime of Stipp et al. (2002b, 2010; Figs. 9, 10 and 12; Kidder et al., 2012), and hypothesize that $\mathrm{Ti}$ concentrations in the fine grains were reset in essentially the same fashion as we propose above for the mid-sized grains, i.e. exchange of Ti between quartz and grain boundaries during grain boundary $\mathrm{mi}-$ gration.

\subsection{Ti diffusivity along grain boundaries}

Grain boundary migration cannot alone explain the observed changes in Ti concentration in recrystallized quartz. Significant amounts of $\mathrm{Ti}$ disappeared from recrystallized regions (e.g. Fig. 10), and resulting Ti concentrations appear to have approached equilibrium with Ti-bearing phases typically found at distances of $\sim 100 \mu \mathrm{m}$ or more. Ti did not remain within grain boundaries adjacent to recrystallized quartz since SIMS analyses (spot size $\sim 10 \mu \mathrm{m}$ ) of finegrained regions (grain size $\sim 10 \mu \mathrm{m}$ ) often intersected grain boundaries but do not show high-Ti spikes (Figs. 15c, 16). It follows that grain boundary diffusion played an important role in the redistribution of Ti during recrystallization. An order of magnitude Ti diffusivity along grain boundaries of $\mathrm{D}$ $>10^{-22} \mathrm{~m}^{2} \mathrm{~s}^{-1}$ is estimated by squaring the $100 \mu \mathrm{m}$ distance and dividing by the time scale $\left(3.5 \mathrm{~m} \mathrm{yr}^{-1}\right)$ over which $\mathrm{Ti}$ diffusion occurred. Diffusivity could be substantially larger than this value, since diffusion probably occurred on a much shorter time scale to allow for continuous Ti diffusion during the migration of grain boundaries. The estimated diffusivity is $>10^{5}$ times higher than predicted rates of lattice diffusion of Ti in quartz at similar temperatures (Cherniak, 2007).

\subsection{Bias and uncertainty of TitaniQ thermobarometry at low temperatures}

A major uncertainty associated with Ti-in-quartz thermobarometry in greenschist facies rocks is the potential loss of accuracy associated with extrapolating trends from laboratory calibrations to quartz crystallized or recrystallized 
Table 2. Estimated bias $(\Delta T)$ and uncertainty $(\sigma)$ of TitaniQ temperature estimates using the Thomas et al. (2010) and Huang and Audétat (2012, "H\&A") calibrations. Positive values of bias indicate an overestimate by TitaniQ relative to independent constraints.

\begin{tabular}{llrr}
\hline Type & Calibration & $\Delta T$ & st. dev. $(\sigma)$ \\
\hline quartzite recrystallization & Thomas & $12(+16 /-14)$ & $104(+18 /-16)$ \\
quartzite recrystallization & H\&A & $136(+16 /-20)$ & $126(+22 /-16)$ \\
vein emplacement & Thomas & $-22(+6 /-8)$ & $52(+8 /-6)$ \\
vein emplacement & H\&A & $80(+6 /-8)$ & $62(+10 /-6)$ \\
\hline
\end{tabular}

at temperatures many hundreds of degrees below laboratory conditions. A rough estimate of the goodness of fit of our results can be made by comparing the TitaniQ predictions of Thomas et al. (2010) and Huang and Audétat (2012) with measured Ti concentrations as depicted in Figs. 2, 14, and 15. The fit can be quantified if we assume that the TitaniQ thermometer is systematically biased by $\Delta T$ and that errors are normally distributed with a variance $\sigma^{2}$. We can then estimate $\Delta T$ and $\sigma$ from their probability distributions computed from the estimated TitaniQ temperatures $\left(T_{\mathrm{o}}\right)$ and independent constraints on temperature $T_{\min }$ and $T_{\max }$ using

$\rho_{i}(\sigma, \Delta T)=\alpha \int_{T \min }^{T \max } \frac{1}{\sqrt{2 \pi \sigma}} \exp \left(-\frac{\left(T-T_{\mathrm{o}}-\Delta T\right)^{2}}{2 \sigma^{2}}\right) d T$

where $\rho$ is probability, $T_{\mathrm{O}}$ is a TitaniQ temperature estimate, $T$ is temperature, and $\alpha$ is a normalization factor. The product of the probabilities $\rho$ of a group of analyses yields a probability density function in $\sigma-\Delta T$ space. The results of pooled analyses for vein emplacement (using only the eight veins with minimum and maximum constraints on temperature) and quartzite recrystallization are given in Table 2 . For vein emplacement we estimate a bias of $-22^{\circ} \mathrm{C}+8 /-6(67 \%$ confidence interval) and $80^{\circ} \mathrm{C}+8 /-6$ using the Thomas et al. (2010) and Huang and Audétat (2012) calibrations respectively. For quartzite recrystallization we calculate biases of $12{ }^{\circ} \mathrm{C}$ and $136^{\circ} \mathrm{C}$.

The bias values calculated above using the Thomas et al. (2010) calibration are small, and considering the multiple sources of potential error, there is good accord between our results and the Thomas et al. (2010) calibration. We believe the difference in estimated bias between the veins and quartzites results in part from the higher concentration of high Ti outliers in recrystallized quartzites (note the skew of the distribution of the fully recrystallized grains in Fig. 15). This is probably due to a combination of incomplete equilibration from initial conditions (detrital grains in the Tachien sandstone are dominantly high $\mathrm{Ti}$ ) and a higher concentration of impurities in the quartzite than the veins. While a more "hands on" approach to filtering anomalous SIMS cycles and potential outliers would reduce this difference, it would introduce a set of judgment calls needed to distinguish "real" quartz analyses and analyses of inclusions. We are unaware of an established, rigorous procedure for distinguishing between inclusions and high impurity concentration minerals.

\subsection{Constraints on Hsüehshan range deformation conditions and timing}

The thermomechanical model of Simoes et al. (2007) required two phases of deformation to match thermochronologic and metamorphic constraints in the Hsüehshan range. The early phase is characterized by slow uplift and erosion rates throughout the orogenic wedge, and the second by underplating and increased uplift rates in the Hsüehshan range. Geologic evidence also suggests a two-phase evolution of the Hsüehshan range, with early deformation characterized by penetrative horizontal compression responsible for over $30 \mathrm{~km}$ of shortening (Fisher et al., 2002), and later deformation marked by out of sequence thrusts (Tillman and Byrne, 1996). We suggest that the two phases proposed by the different research groups correspond to the same two geologic phases. This constrains the timing of the upright folding, subvertical cleavage, and strain markers described by Clark et al. (1993) and Tillman and Byrne (1995) to before $~ 4 \mathrm{Ma}$, the timing of phase two onset in the model of Simoes et al. (2007). The second phase of deformation may continue to the present-day, where little or no internal shortening in the Hsüehshan range is observed (Simoes and Avouac, 2006).

Previous studies of the Hsüehshan range have documented deformation under retrograde conditions (Clark et al., 1993) and concluded that peak metamorphism of the Hsüehshan range occurred "statically," prior to collision (Beyssac et al., 2007). In the course of our study we noted features from the core of the Tachien anticline indicating that compressional deformation occurred while temperatures were at or near peak conditions. First, metamorphic biotite, originally noted by Yen (1973), grew in pressure shadows oriented consistently with compressional deformation (Fig. 8). Second, the migration of grain boundaries in the quartzite samples across distances of 50-60 $\mu \mathrm{m}$ (e.g. Fig. 12) is indicative of high-temperature grain-boundary migration recrystallization (Stipp et al., 2002b). These features indicate early deformation at temperatures of at least $\sim 400^{\circ} \mathrm{C}$ (Stipp et al., 2002b; Bucher and Grapes, 2011), somewhat warmer than modeled by Simoes et al. (2007; Figs. 4, 6). This early hightemperature deformation may have resulted from thickening at the toe of the orogenic wedge under ambient PT conditions prior to significant motion on the decollement beneath the Hsüehshan range. 


\subsection{Recommendations for future TitaniQ studies}

Grujic et al. (2011) found that Ti concentrations did not change during bulging recrystallization in mylonitic veins, whereas we document resetting of Ti in quartzites deformed within the bulging regime at similar temperatures. What led to the different behaviours in the two settings? One possibility is that the time scales of deformation were significantly different. Grujic et al. (2011) suggest that the deformation of the Tonale mylonites occurred in $<1 \mathrm{Myr}^{-1}$, whereas deformation in the Tachien anticline may have lasted as long as $3.5 \mathrm{Myr}^{-1}$. A second possibility is that quartzites are more likely to reset with respect to Ti content during dynamic recrystallization than vein quartz. In the Grujic et al. (2011) study, the lack of resetting of $\mathrm{Ti}$ in recrystallized vein quartz may result from an absence or scarcity of Ti-bearing phases within veins in the vicinity of recrystallized quartz. Future studies could test this hypothesis by analyzing quartz recrystallized at various distances from vein edges.

As a new technique, the applicability of TitaniQ thermobarometry is debated (e.g. Thomas and Watson, 2012; Wilson et al., 2012), and further field-based tests in wellconstrained localities are warranted before Ti-concentrations in quartz can be confidently interpreted in terms of PT conditions. Many previous studies have focused on Tiundersaturated systems, and considerable effort has been expended attempting to simultaneously determine Ti activity and test TitaniQ (e.g. Grujic et al., 2011; Wilson et al., 2012). A priority for the next phase of field-based TitaniQ studies should be the deconvolution of these two sources of uncertainty by carrying out studies in rocks containing rutile.

An additional uncertainty in Ti-in-quartz thermobarometry, not previously discussed, is the possibility that the relevant pressure term in the TitaniQ equation is fluid pressure rather than lithostatic pressure as generally assumed (though not stated, e.g. Behr and Platt, 2011; Grujic et al., 2011). In many situations these pressure terms are likely to be equal, e.g. magmas, deep crustal rocks, and the experimental capsules used to calibrate TitaniQ. Near the brittleductile transition however, fluid pressure may often be sublithostatic (e.g. Küster and Stöckhert, 1998; Townend and Zoback, 2000). In the Hsüehshan range, differential stress estimates require nearly hydrostatic fluid pressure (Kidder et al., 2012), since effective pressure $\left(P_{\text {lithostatic }}-P_{\text {fluid }}\right)$ must be greater than differential stress in order for dislocation creep and dynamic recrystallization to occur (Kohlstedt et al., 1995). Vein quartz certainly forms in the presence of fluid, and fluids may also be present along grain boundaries during grain boundary migration (e.g. Urai et al., 1986; Hippertt, 1994; Mancktelow and Pennacchioni, 2004). It is possible that Ti concentrations in quartz in these settings are a function of fluid pressure rather than lithostatic pressure. Were this the case, temperatures based on Thomas et al. (2010) would be $\sim 30-40^{\circ} \mathrm{C}$ lower than calculated above. Used with fluid pressure, the Huang and Audétat (2012) equation would give results more consistent with the independent constraints above, however this combination significantly overpredicts temperature in higher grade rocks where fluid pressures were likely lithostatic (e.g. the data presented by Storm and Spear, 2009). Considering the importance of fluid pressure in the crust (e.g. Townend and Zoback, 2000), further exploration of the sensitivity of TitaniQ to different types of pressure is warranted.

\section{Supplementary material related to this article is available online at: http://www.solid-earth.net/4/1/2013/ se-4-1-2013-supplement..pdf.}

Acknowledgements. The manuscript directly benefited from interactions with Michel Bestmann, Jeremy Boyce, John Eiler, Aaron Martin, Mike Palin, Jason Saleeby, Martine Simoes, James Scott, Joann Stock, Marion Le Voyer, and Brian Wernicke. Chih-Tung Chen, Chung Huang, Aaron Martin, Shiao An-Yu, and Yong Chi-Kai are thanked for their assistance in the field. Yunbin Guan, Chi Ma, Jeremy Boyce, and Marion Le Voyer provided helpful assistance with the SEM and SIMS. Robin Kidder helped with illustrations and many other aspects of the work. John Platt and the Pasadena Rheological Society are thanked for providing a forum for discussing all things microstructural. Jay Thomas provided us with an experimental sample that aided in SIMS calibration. Reviews by Frank Spear and Whitney Behr significantly improved the manuscript. Financial support was provided by the Gordon and Betty Moore Foundation via Caltech's Tectonics Observatory. This is Caltech Tectonic Observatory contribution 217.

Edited by: D. J. J. van Hinsbergen

\section{References}

Behr, W. M., Thomas, J., and Hervig, R.: Calibrating Ti concentrations in quartz on the SIMS using NIST silicate glasses with applications to the TitaniQ geothermobarometer, Am. Mineral., 96, 1100-1106, doi:10.2138/am.2011.3702, 2010.

Behr, W. M. and Platt, J. P.: A naturally constrained stress profile through the middle crust in an extensional terrane, Earth Planet Sci. Lett., 303, 181-192, doi:10.1016/J.Epsl.2010.11.044, 2011.

Beyssac, O., Bollinger, L., Avouac, J. P., and Goffé, B.: Thermal metamorphism in the Lesser Himalaya of Nepal determined from Raman spectroscopy of carbonaceous material, Earth Planet. Sci. Lett., 225, 233-241, 2004.

Beyssac, O., Simoes, M., Avouac, J. P., Farley, K. A., Chen, Y.-G., Chan, Y.-C., and Goffé, B.: Late Cenozoic metamorphic evolution and exhumation of Taiwan, Tectonics, 26, 1-32, 2007.

Bucher, K. and Grapes, R.: Petrogenesis of Metamorphic Rocks, 8 Edn., Springer-Verlag, 428 pp., 2011.

Chen, C. T., Chan, Y. C., Lu, C. Y., Simoes, M., and Beyssac, O.: Nappe structure revealed by thermal constraints in the Taiwan metamorphic belt, Terra Nova, 23, 85-91, doi:10.1111/J.13653121.2011.00987.X, 2011. 
Cherniak, D. J., Watson, E. B., and Wark, D. A.: $\mathrm{Ti}$ diffusion in quartz, Chem. Geol., 236, 65-74, doi:10.1016/J.Chemgeo.2006.09.001, 2007.

Clark, M. B., Fisher, D. M., and Lu, C.-Y.: Strain Variations in the Eocene and older rocks exposed along the Central and Southern Cross-Island Highways, Taiwan, Acta Geologica Taiwanica Science Reports of the National Taiwan University, 30, 1-10, 1992.

Clark, M. B., Fisher, D. M., Lu, C.-Y., and Chen, C.-H.: Kinematic analyses of the Hsüehshan range, Taiwan: A large-scale pop-up structure, Tectonics, 12, 205-217, 1993.

De Laeter, J. R., Bohlke, J. K., De Bievre, P., Hidaka, H., Peiser, H. S., Rosman, K. J. R., and Taylor, P. D. P.: Atomic weights of the elements: Review 2000 - (IUPAC technical report), Pure Appl. Chem., 75, 683-800, 2003.

Dresen, G., Duyster, J., Stöckhert, B., Wirth, R., and Zulauf, G.: Quartz dislocation microstructure between $7000 \mathrm{~m}$ and $9100 \mathrm{~m}$ depth from the Continental Deep Drilling Program KTB, J. Geophys. Res., 102, 18443-18452, 1997.

Dunlap, W., Hirth, G., and Teyssier, C.: Thermomechanical evolution of a ductile duplex, Tectonics, 16, 983-1000, 1997.

Fisher, D. M., Lu, C.-Y., and Chu, H. T.: Taiwan Slate Belt: Insights into the ductile interior of an arc-continent collision, in: Geology and Geophysics of an Arc-Continent Collision, Taiwan, edited by: Byrne, T. and Liu, C. S., Geological Society of America Special Paper 358, Boulder, Colorado, 93-106, 2002.

Grujic, D., Stipp, M., and Wooden, J. L.: Thermometry of quartz mylonites: Importance of dynamic recrystallization on Ti-in-quartz reequilibration, Geochem. Geophys. Geosyst., 12, Q06012, doi:10.1029/2010GC003368, 2011.

Hippertt, J.: Grain boundary microstructures in micaceous quartzite: significance for fluid movement and deformation processes in low metamorphic grade shear zones, The Journal of Geology, 102, 331-348, 1994.

Hirth, G. and Tullis, J.: Dislocation creep regimes in quartz aggregates, J. Struct. Geol., 14, 145-159, 1992.

Hirth, G., Teyssier, C., and Dunlap, W.: An evaluation of quartzite flow laws based on comparisons between experimentally and naturally deformed rocks, Int. J. Earth Sci. (Geol Rundsch), 90, 7787, 2001.

Ho, C. S.: A synthesis of the geologic evolution of Taiwan, Tectonophysics, 125, 1-16, 1986.

Ho, C. S.: An introduction to the geology of Taiwan: explanatory text of the geologic map of Taiwan, 2 Edn., Central Geological Survey, Ministry of Economic Affairs, Taipei, Taiwan, Republic of China, 192 pp., 1988.

Huang, R. and Audétat, A.: The titanium-in-quartz (TitaniQ) thermobarometer: A critical examination and re-calibration, Geochim. Cosmochim. Ac., 84, 75-89, doi:10.1016/j.gca.2012.01.009, 2012.

Jochum, K., Nohl, U., Herwig, K., Lammel, E., Stoll, B., and Hofmann, A.: GeoReM: A new geochemical database for reference materials and isotopic standards, Geostandards Newsletters, 22, 7-13, 2005.

Kawasaki, T. and Osanai, Y.: Empirical thermometer of $\mathrm{TiO} 2$ in quartz for ultrahigh-temperature granulites of East Antarctica, Geological Society, London, Special Publications, 308, 419-430, doi:10.1144/sp308.21, 2008.

Kidder, S., Avouac, J. P., and Chan, Y. C.: Constraints from rocks in the Taiwan orogen on crustal stress levels and rheology, J. Geo- phys. Res., 117, B09408, doi:10.1029/2012JB009303, 2012.

Kohlstedt, D. L., Evans, B., and Mackwell, S. J.: Strength of the lithosphere-constraints imposed by laboratory experiments, J. Geophys. Res.-Sol. Ea., 100, 17587-17602, 1995.

Kohn, M. J. and Northrup, C. J.: Taking mylonites' temperatures, Geology, 37, 47-50, doi:10.1130/G25081A.1, 2009.

Küster, M. and Stöckhert, B.: High differential stress and sublithostatic pore fluid pressure in the ductile regime - microstructural evidence for short-term post-seismic creep in the Sesia Zone, Western Alps, Tectonophysics, 1998, 263-277, 1998.

Lin, A. T., Watts, A. B., and Hesselbo, S. P.: Cenozoic stratigraphy and subsidence history of the South China Sea margin in the Taiwan region, Basin Research, 15, 453-478, doi:10.1046/j.13652117.2003.00215.x, 2003.

Liu, T. K., Hsieh, S., Chen, Y. G., and Chen, W. S.: Thermokinematic evolution of the Taiwan oblique-collision mountain belt as revealed by zircon fission track dating, Earth Planet. Sci. Lett., 186, 45-56, 2001.

Lu, C. Y., Lee, J. C., and Lee, J. F.: Extensional and compressional tectonics in central Taiwan, in: Neotectonics and Resources, edited by: Cosgrove, J., and Jones, M., Belhaven Press, London and New York, 85-92, 1991.

Lu, C. Y.: The development of the vein system in central Taiwan: a case study of the section from Kukua to Tekee along the Central Cross Island Highway, J. Geol. Soc., 35, 77-94, 1992.

Lu, C. Y., Chu, H. T., and Lee, J. C.: Structural evolution in the Hsüehshan range Hsüehshan range, Taiwan, J. Geol. Soc., 40, 261-279, 1997.

Mancktelow, N. S. and Pennacchioni, G.: The influence of grain boundary fluids on the microstructure of quartz-feldspar mylonites, J. Struct. Geol., 26, 47-69, doi:10.1016/s01918141(03)00081-6, 2004.

Menegon, L., Nasipuri, P., Stünitz, H., Behrens, H., and Ravna, E.: Dry and strong quartz during deformation of the lower crust in the presence of melt, J. Geophys. Res., 116, B10410, doi:10.1029/2011jb008371, 2011.

Muto, J., Nagahama, H., and Hashimoto, T.: Water distribution in dynamically recrystallized quartz grains: cathodoluminescence and micro-infrared spectroscopic mapping, in: High-Strain Zones: Structure and Physical Properties, edited by: Bruhn, D. and Burlini, L., Geol. Soc., London, 397-407, 2005.

Pennacchioni, G., Menegon, L., Leiss, B., Nestola, F., and Bromiley, G.: Development of crystallographic preferred orientation and microstructure during plastic deformation of natural coarsegrained quartz veins, J. Geophys. Res.-Sol. Ea., 115, B12405, doi:10.1029/2010jb007674, 2010.

Peterman, E. M. and Grove, M.: Growth conditions of symplectic muscovite plus quartz: Implications for quantifying retrograde metamorphism in exhumed magmatic arcs, Geology, 38, 10711074, doi:10.1130/G31449.1, 2010.

Raimondo, T., Clark, C., Hand, M., and Faure, K.: Assessing the geochemical and tectonic impacts of fluid-rock interaction in mid-crustal shear zones: a case study from the intracontinental Alice Springs Orogen, Central Australia, J. Metamorphic Geol., 29, 821-850, doi:10.1111/j.1525-1314.2011.00944.x, 2011.

Rasmussen, B., Fletcher, I. R., Muhling, J. R., Gregory, C. J., and Wilde, S. A.: Metamorphic replacement of mineral inclusions in detrital zircon from Jack Hills, Australia: Implications for the Hadean Earth, Geology, 39, 1143-1146, doi:10.1130/g32554.1, 
2011.

Rusk, B. G., Reed, M., H., Dilles, J. H., and Kent, A. J. R.: Intensity of quartz cathodoluminescence and trace-element content in quartz from the porphyry copper deposit at Butte, Montana, Am. Mineral., 91, 1300-1312, 2006.

Rusk, B. G., Lowers, H. A., and Reed, M., H.: Trace elements in hydrothermal quartz: Relationships to cathodoluminescent textures and insights into vein formation, Geology, 36, 547-550, 2008.

Rusk, B. G., Koenig, A., and Lowers, H. A.: Visualizing trace element distribution in quartz using cathodoluminescence, electron microprobe, and laser ablation-inductively coupled plasma-mass spectrometry, Am. Mineral., 96, 703-708, 2011.

Sella, G. F., Dixon, T. H., and Mao, A. L.: REVEL: A model for recent plate velocities from space geodesy, J. Geophys. Res.-Sol. Ea., 107, 2081, doi:10.1029/2000jb000033, 2002.

Simoes, M. and Avouac, J. P.: Investigating the kinematics of mountain building in Taiwan from the spatiotemporal evolution of the foreland basin and western foothills, J. Geophys. Res., 111, 125, 2006.

Simoes, M., Avouac, J. P., Beyssac, O., Goffé, B., Farley, K. A., and Chen, Y.-G.: Mountain building in Taiwan: A thermokinematic model, J. Geophys. Res., 112, 1-25, 2007.

Spear, F. S., and Wark, D. A.: Cathodoluminescence imaging and titanium thermometry in metamorphic quartz, J. Metamorphic Geol., 27, 187-205, 2009.

Stipp, M., Stünitz, H., Heilbronner, R., and Schmid, S. M.: The eastern Tonale fault zone: a "natural laboratory" for crystal plastic deformation of quartz over a temperature range from 250 to $700^{\circ} \mathrm{C}$, J. Struct. Geol., 24, 1861-1884, $2002 \mathrm{a}$.

Stipp, M., Stünitz, H., Heilbronner, R., and Schmid, S. M.: Dynamic recrystallization of quartz: correlation between natural and experimental conditions, Geol. Soc. Spec. Publ., 200, 171-190, 2002b.

Stipp, M. and Tullis, J.: The recrystallized grain size piezometer for quartz, Geophys. Res. Lett., 30, 2088, doi:10.1029/2003GL018444, 2003.

Stipp, M., Tullis, J., Scherwath, M., and Behrmann, J. H.: A new perspective on paleopiezometry: Dynamically recrystallized grain size distributions indicate mechanism changes, Geology, 38, 759-762, doi:10.1130/G31162.1, 2010.

Stöckhert, B., Brix, M. R., Kleinschrodt, R., Hurford, A. J., and Wirth, R.: Thermochronometry and microstructures of quartzcomparison with experimental flow laws and predictions on the temperature of the brittle-plastic transition, J. Struct. Geol., 21, 351-369, 1999.

Storm, L. C. and Spear, F. S.: Application of the titanium-in-quartz thermometer to pelitic migmatites from the Adirondack Highlands, New York, Journal of Metamorphic Geology, 27, 479-494, doi:10.1111/j.1525-1314.2009.00829.x, 2009.

Thomas, J. and Watson, E.: Application of the Ti-in-quartz thermobarometer to rutile-free systems, Reply to: A comment on: "TitaniQ under pressure: the effect of pressure and temperature on the solubility of Ti in quartz", Contributions to Mineralogy and Petrology, 164, 369-374, doi:10.1007/s00410-012-0761-5, 2012.
Thomas, J. B., Watson, E. B., Spear, F. S., Shemella, P. T., Nayak, S. K., and Lanzirotti, A.: TitaniQ under pressure: the effect of pressure and temperature on the solubility of $\mathrm{Ti}$ in quartz, Contributions to Mineralogy and Petrology, 160, 743759, doi:10.1007/s00410-010-0505-3, 2010.

Tillman, K. S., Byrne, T. B., and Lu, C.-Y.: Pre-collision extensional structures from the central range, Taiwan: implications for the kinematic evolution of the South China Margin, Acta Geologica Taiwanica, 30, 11-26, 1992.

Tillman, K. S. and Byrne, T. B.: Kinematic analysis of the Taiwan Slate Belt, Tectonics, 14, 322-341, 1995.

Tillman, K. S. and Byrne, T. B.: Out-of-sequence thrusting in the Taiwan Slate Belt, J. Geol. Soc., 39, 189-208, 1996.

Townend, J. and Zoback, M. D.: How faulting keeps the crust strong, Geology, 28, 399-402, 2000.

Tsan, S. F.: Structural geology of the southern Hsüehshan range, Taiwan, Proc. Geol. Soc. China, 14, 62-75, 1971.

Tsao, S. J.: The geological significance of illite crystallinity, zircon fission-track ages and K-Ar ages of metasedimentary rocks of the Central Range, Ph.D., National Taiwan University, Taipei, 272 pp., 1996.

Urai, J. L., Means, W. D., and Lister, G. S.: Dynamic recrystallization of minerals, in: Mineral and rock deformation: laboratory studies, The Paterson Volume, Geophysical Monograph 36, edited by: Hobbs, B. E. and Heard, H. C., American Geophysical Union, Washington, DC, 161-199, 1986.

van Daalen, M., Heilbronner, R., and Kunze, K.: Orientation analysis of localized shear deformation in quartz fibres at the brittleductile transition, Tectonophysics, 303, 83-107, 1999.

Voll, G.: Recrystallization of quartz, biotite and feldspars from Erstfeld to the Leventina nappe, Swiss Alps, and its geological significance, Schweizer Mineralogische und Petrographische Mitteilungen, 56, 641-647, 1976.

Wark, D. and Spear, F.: Ti in quartz: Cathodoluminescence and thermometry, Goldschmidt 2005, A592, 2005.

Wark, D. A. and Watson, B.: TitaniQ: a titanium-in-quartz geothermometer, Contrib. Mineral. Petr., 2006, 743-754, 2006.

Wilson, C. J. N., Seward, T. M., Allan, A. S. R., Charlier, B. L. A., and Bello, L.: A comment on: "TitaniQ under pressure: the effect of pressure and temperature on the solubility of Ti in quartz", edited by: Thomas, J. B., Watson, E. B., Spear, F. S., Shemella, P. T., Nayak, S. K., and Lanzirotti, A., Contrib. Mineral. Petr., 164, 359-368, doi:10.1007/s00410-012-0757-1, 2012.

Yen, T. P.: The Eocene sandstones in the Hsüehshan range terrain, Northern Taiwan, Proc. Geol. Soc. China, 16, 97-110, 1973.

Zhou, D., Yu, H.-S., Xu, H.-H., Shi, X.-B., and Chou, Y.-W.: Modeling of thermo-rheological structure of lithosphere under the foreland basin and mountain belt of Taiwan, Tectonophysics, 374, 115-134, doi:10.1016/s0040-1951(03)00236-1, 2003. 